\title{
Campus Planning and Architecture: A comparative Study of Kwame Nkrumah University of Science and Technology (KNUST) and University of Ghana (LEGON)
}

\author{
Onassis Lartey ${ }^{1}$, Alexander Boakye Marful ${ }^{2}$.
}

1 Department of Architecture, Kwame Nkrumah University of Science and Technology; onassislartey@gmail.com

2 Department of Architecture, Kwame Nkrumah University of Science and Technology; amarful@yahoo.com

* Correspondence: e-mail@e-mail.com; Tel.: (optional; include country code; if there are multiple corresponding authors, add author initials)

\begin{abstract}
A university campus is a place full of memorable experiences and a sense of place. It is an environment that potentially creates a social and intellectual exchange of ideas and brings together diverse people. Campus planning is one essential need for any higher institution and is an instrument used for directing, promoting, and securing orderly physical development of an institution Campus planning present unique opportunities for demonstrating and popularizing contemporary tendencies in urban planning. The purpose of this study is to explore the overall concepts of the campus planning and architecture of the Kwame Nkrumah University of Science and Technology (Knust) And University of Ghana (Legon). The Study was based mainly on two methods; Documentary research and qualitative Observation to have in depth knowledge about the campuses. Through field observation, the study was limited to the spatial organization and planning, site layout and master planning, land use, use of space, and architectural details. The study adopts A Comparative Analysis Approach and found out that Campus Planning Concept varies and unique to campuses and in developing a campus plan, it involves a time-consuming dynamic process and besides, there are neither shortcuts nor one approach or generic solution to that. The study also revealed that Iconic and unique buildings are usually found on university campuses.
\end{abstract}

Keywords: University; Campus Planning; Architecture

\section{Introduction}

The Universities have taken trends in a non-stop continuous growth leading to campus expansion. The Universities must anticipate possible growth, enrolment increase, and change. The needs for an increase in facilities arise and College facilities and other spaces are created and in due effect, campus planning concepts and architecture continue to be altered or change. The universities decline their campuses and architecture of architectural style and originality. Most old existing buildings on the campuses reflect architectural meanings besides the new buildings are with little or without architectural meanings and significance. The universities now face an architectural issue of maintaining an architectural character or pattern and a comprehensive campus planning and have a great challenge of providing flexibility and indeterminacy.

2. Materials and Methods

The scope of this study is the physical aspects of the university campuses concerning its planning and architecture. Case studies are the Kwame Nkrumah University of Science and Technology (Knust) And University of Ghana (Legon).

The purpose of this study is to explore the overall concepts of the campus planning and architecture of the Kwame Nkrumah University of Science and Technology (Knust) And University of Ghana (Legon). The Study was based mainly on two methods; Documentary research and qualitative Observation to have in depth knowledge about the 
campuses. Through field observation, the study was limited to the spatial organization and planning, site layout and master planning, land use, use of space, and architectural details. This seeks to identify varying concepts and approach to campus design and architecture. The study finally adopts A Comparative Analysis Approach.

\section{Literature Discussion}

\subsection{Campus Planning}

The planning of campuses is an essential requirement for any higher institution. Campus planning is a tool that is used to direct, facilitate, and protect an institution's organized physical development. It is also the mechanism for implementing and controlling the development and effective management of the campus infrastructure and facilities. University campus planning offers unique ways to demonstrate and popularize emerging developments in urban planning and guides for the size, quality, usage, and location of facilities to achieve a preconceived goal. The design is typically represented as a physical form, and the form will differ from an aspect of the entire campus buildings and surrounding area depending on the scope.

Campus planning affects the campus environment besides the socio-economic development of the campus as well. Thus, needs to reflect the mandate and purpose of the university. (Norton et al, 2007). Campuses are normally likened to cities due to their high independent elements. According to Dober (1964), campuses are in three parts, which are, the physical buildings, open areas, and supporting spaces and elements which include services and circulation. Dober said that the supporting elements are necessary to sustain the operations of the campus. He also mentioned clearly, building separately or isolating buildings from its surroundings should be avoided and develop an interdependency consciousness when planning. Walker and Gough (1962), also added that continuous campus development designed and built by different teams or firms leads to varying building styles and forms. Buildings should be designed or inspired by the existing old campus buildings to maintain unity throughout the entire campus architecture (Walker and Gough, 1962).

\subsection{Principles of Campus Planning}

It is recommended to follow the principles of urban planning while planning campus. For a campus to work effectively gradually with time, it must be flexible enough to handle anticipated changes and developments. Campus planning principles serve as a guide to the physical development of the campus, enhances the natural, cultural, the overall aesthetics of the campus and also provide a physical planning framework for the campus which serves as a tool for evaluating future land-use proposals for guiding the type, size, and location of future facilities.

\subsubsection{Identity and character}

Campus identity emerges from the uniqueness of the buildings and landscape that define these spaces and offer campus a visually cohesive and aesthetically pleasing recognition. Existing buildings, new buildings, and spaces should be linked in an inter-connected composition. Entry features should be appropriately scaled and well designed in inconsistency, with the character of the campus and a sense of arrival. (TURNER, 1984)

\subsubsection{Site Layout and Landuse}

Campus core clustered with development and a loop system is encouraged to enhance workability. Provide a diversity of usable open spaces, protect and conserve perimeter lands for future use. Establishment of pedestrian and vehicular connections with neighboring properties to promote its end-user convenience, facilities, and positive synergies. A comprehensive network development of diverse open spaces to promote formal as well as informal interactions 
Design buildings scaled to human physical capabilities, in other words (humanscaled spaces) that relate to the size, mass, and proportion of the surrounding structures, the streets, and public ways adjacent to them. The campus should be organized in logical districts of compatible land use. Promote compact campus development to preserve, conserve, and protect existing natural areas and maximizes land productivity to enhance functional efficiencies. (TURNER, 1984)

\subsubsection{Architecture}

It is very important to understand the individual role of buildings in planning and building a campus. Buildings or architecture on campuses should incorporate historical references. A design that draws inspiration from history. Buildings should have character and should express aesthetic ideas. Architectural design guidelines for design elements related to scale, materials, color, etc. should be developed to achieve a varying yet coherent architecture. (TURNER, 1984)

\subsubsection{Orientation}

Campus buildings are mostly seen from street boundaries as well as the interior of campuses and also lower ones from above and should be designed to contribute to buildings streets and pedestrian ways from either side. Buildings should be oriented properly concerning the sun. Ideally, an east-west orientation that is, a rectangular ratio of 1 (eastwest) to between 1.5 and 2 (north-south) on an east-west axis.

Exterior Visual connection and interaction for occupants should be a core design element. Averagely, there should be $10 \%$ to $25 \%$ south-facing glass of the floor area of each building. South-facing glazing should be maximized with sunscreens and shades to reduce solar heat gain and thereby maximizing daylighting and glare control. (TURNER, 1984)

\subsubsection{Landscape, Streetscape, and Signage}

Structures should be identified and planned to build vibrant and safe public ways that have day and night wide surveillance from occupants to provide defensive and utilizable spaces.

Make provision for safe bicycle parking areas. Site and street furniture, walkways, and lighting fixtures and systems must be provided on all public spaces to enhance the design of landscape on campus. (TURNER, 1984)

\subsubsection{Circulation and Accessibility}

Equal access to campus by all people regardless of their disabilities, stature, or other factors must be designed for.

The campus should emphasize pedestrian and vehicle in a pedestrian-oriented design to provide a comprehensive, accessible circulation network all over campus to facilitate secure and convenient access across campus.

A pedestrian-oriented campus gives priority to pedestrian access thereby subordinating vehicular systems. Pedestrian routes should be designed to accommodate use and circulation all the time.

The campus should be well accessed by all transportation modes from every direction. Provide a safe and appropriate flow of traffic with clearly defined preferred vehicular routes. (TURNER, 1984)

\section{Case Studies and Results}

\subsection{Case 1, Knust Campus Planning and Architecture}

The Kwame Nkrumah University of Science and Technology (KNUST), originally established by a Government Ordinance as Kumasi College of Technology on 6 October 1951, was converted, a full-fledged university by Parliament Act on August 22, 1961. In February 1966, the name of the institution was changed to the University of Science and Technology by a decree, but by another Parliament Act (Act 559 of 1998). It returned to its original name, Kwame Nkrumah University of Science and Technology in 2000. 
The Campus is approximately seven square miles in area and situated seven kilometers away from the CBD of the Kumasi city. The latitude of the KNUST is 6.673175, and the longitude is -1.565423 with $6^{\circ} 40^{\prime} 23.4300^{\prime} \mathrm{N}$ and $1^{\circ} 33^{\prime} 55.5228^{\prime} \mathrm{W}$ GPS coordinates.

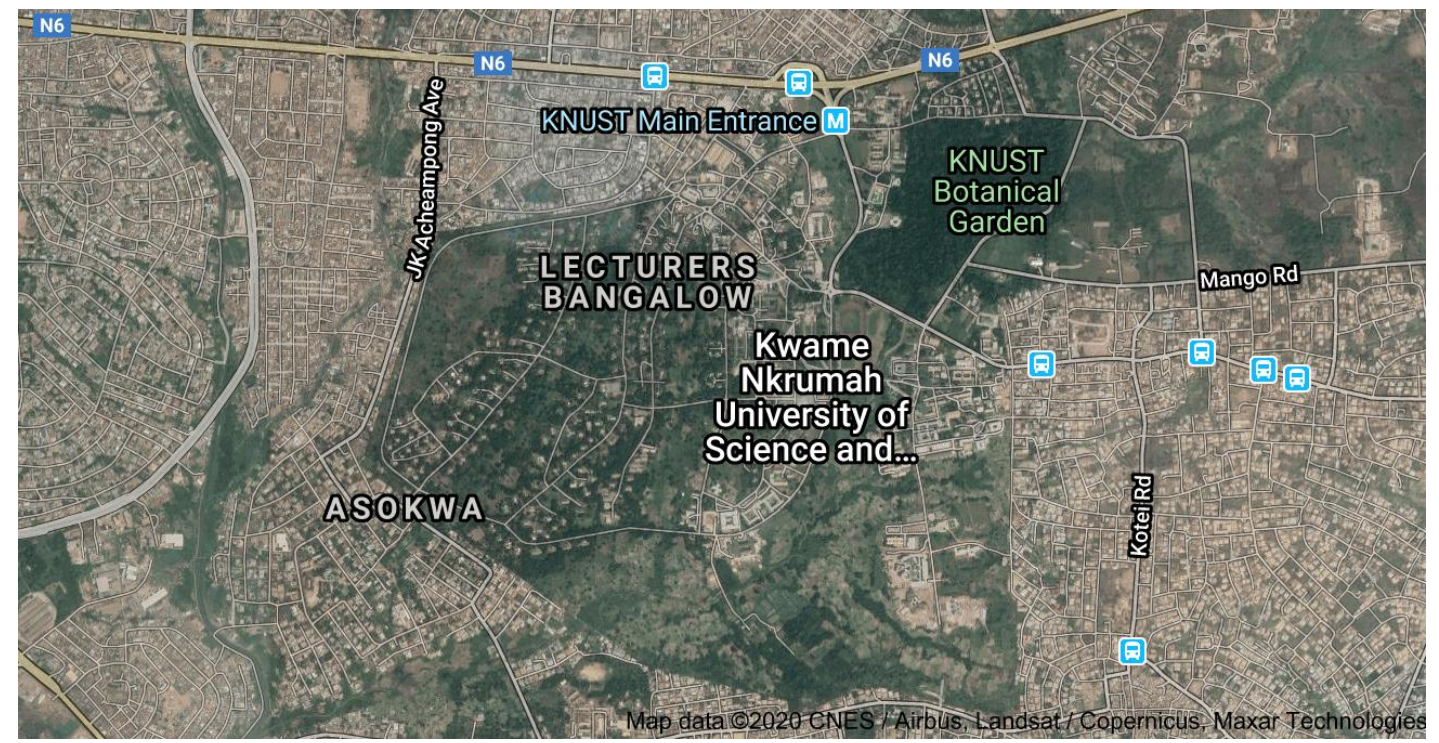

Figure 1: Satellite Map of KNUST

The University of Science and Technology's motto is 'Nyansapo wosane no badwemma' which is literally translated into English as 'Only the wise can untie the knot of wisdom.' A paraphrase of this pithy expression is that knotty issues can only be solved by those who have had the training and expertise to deal with such problems.

\subsubsection{Establishment of the University}

One of the most remarkable events in Ghana's history of higher education during the post-war period was the report presented to the British Parliament by the Secretary of State for the Colonies by His Majesty 's Command in June 1945 from the Commission of Higher Education in West Africa.

This report, popularly known as the 'Elliott Report' after Commission Chairman Sir Walter Elliott, paved the way for the University of Ghana, and later, the University of Science and Technology to be established. The State Secretary's approval of the minority section proposal in the Elliot Commission report, which proposed that 'each of the three major dependencies would constitute a territorial college, led to the creation of the College of Technology, Science and Arts.

In April 1949, a select committee of the Gold Coast Legislature Council was formed to draw up a 'comprehensive scheme for the radical Africanisation of each department of the Public Service over the next ten years, and for the education and training required to provide a sufficient number of eligible African officers to take up senior appointments in the Civil Service and beyond, make recommendations for implementation.'

The Select Committee listed the new 'Regional College to be founded in Kumasi' in their report of November 19, 1949. The report then defined the role that the Regional College could play in implementing the government's Africanization policy, in association with the University College that was already in existence. The report went ahead. Due to the critical demand for accommodation, the expansion of University College became a matter of primary importance. Considered to be made new and permanent buildings were the current quarters which were transient with time.

\subsubsection{Site and Buildings}

The site that makes up the University's campus and other areas were generously offered by the Asantehene the Late Otumfuo Sir Osei Agyeman Prempeh II. Works had 
already begun on clearing the site in January 1951 before the enactment of the ordinance that legalized the existence of the College of Technology, Science, and Arts. Several prefabricated houses have been put up to accelerate the launch of studies. In the almost impossible task of clearing a virgin forest and making it habitable with a few months, it is invidious to mention any individual but if Eichenberg 's name does not appear in it.

Uncle Ike supervised buildings and houses that were urgently required to begin classes in January 1952 as he was familiarly known. By January 1952, prefabricated bungalows were configured along the Okodee Road and ready for accommodation. The Science and General Studies and Teacher Training often had to use a variety of temporary buildings, including the Housecraft Block (which included the laundry, cooking facilities, housewifery and needlework, and a practice house), the School of Arts and Science, the Music Block School and a Gymnasium used by the Physical Education Department.

Besides, temporary buildings were also built to accommodate laboratories for physics, chemistry and botany, and specialist rooms for handwork in geography and education. All these temporary structures had been put up barely a year before the campus began classes. This accomplishment is an eloquent reference to the diligent and committed work Uncle Ike did during the institution's pioneering days.

England's James Cubitt and partners (including Kenneth Scott) were appointed architects for the next building stages, and construction began on the erection of the new teaching blocks in March 1952. Cubitt and his team showed in-depth awareness of the regional environment and accounted for its impacts around the campus in their designs. He viewed the campus as a Park in an educational perspective. The buildings cautiously placed on the campus site and take great benefit of the southern breeze to achieve a calm soothing cool environment... His design at the time was strongly inspired by South American architecture. The landscape in the form of lawns, trees, and shrubs was redesigned with technology in a style.

Buildings of the second phase completed, comprised of the General Lecture Room Block (consisting of 21 lecture and tutorial rooms and seven offices), Pharmacy laboratories (with a total floor area of 33,500 square feet) and Engineering and construction drawing offices and lecture rooms.

The opening ceremony of Kumasi College of Technology, Science, and Arts took place on 30th October 1954. Education Minister Hon. J. H. Allasani delivered the address and formally opened an inspection of the college buildings. The College's building growth was halted during the two previous years when James Cubitt Scott's services and partners were discontinued.

Mr. E. Williamson was appointed staff architect in 1959, and he had a team of four other work architects who had been dormant and designed several buildings. Two halls of residence were built and given on a contract to accommodate 200 students each. The Great Hall, the University Library, and the Laboratories were other buildings in the design stage. By the end of 1957, the building of the 2 Halls of Residence, the Freedom and Queen's, as well as 22 staff houses were all underway.

A U.K firm of architects was appointed by The College Council to draw up a Master Plan of the site. 


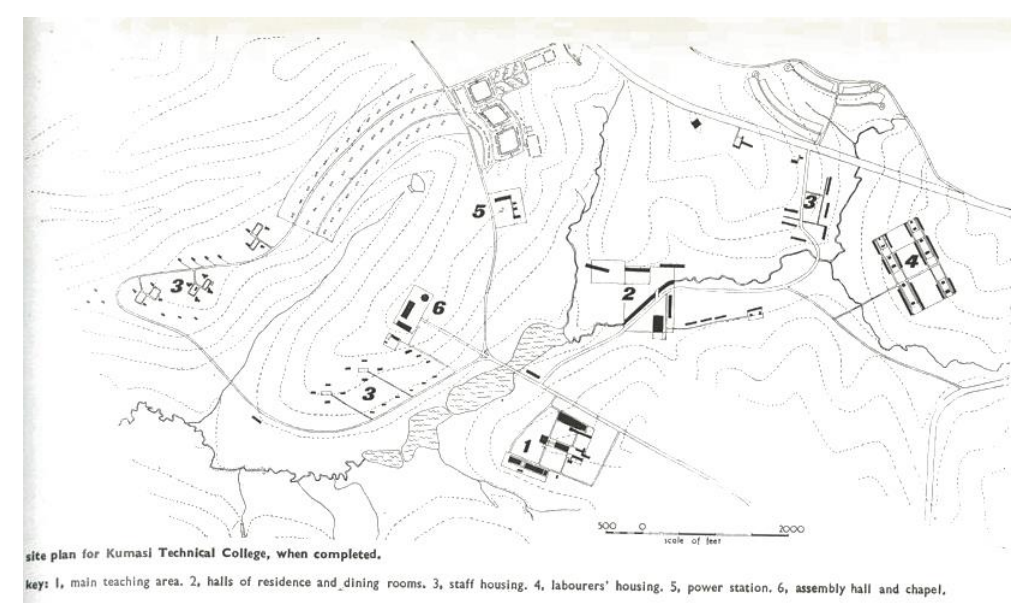

Figure 2: KNUST Master Plan (1956), James Cubitt.

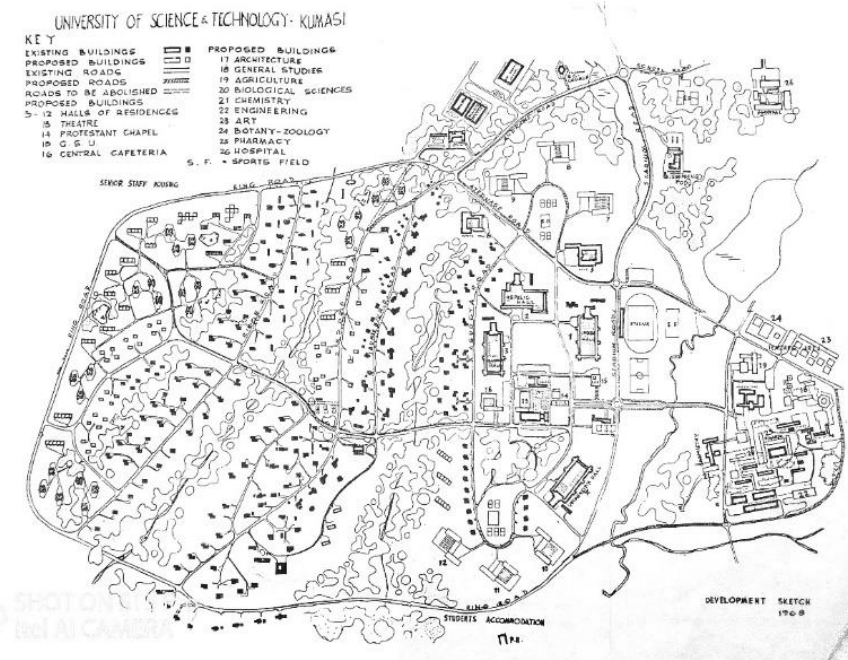

Figure 3: KNUST Master Plan Development Sketch (1968), Wellington.

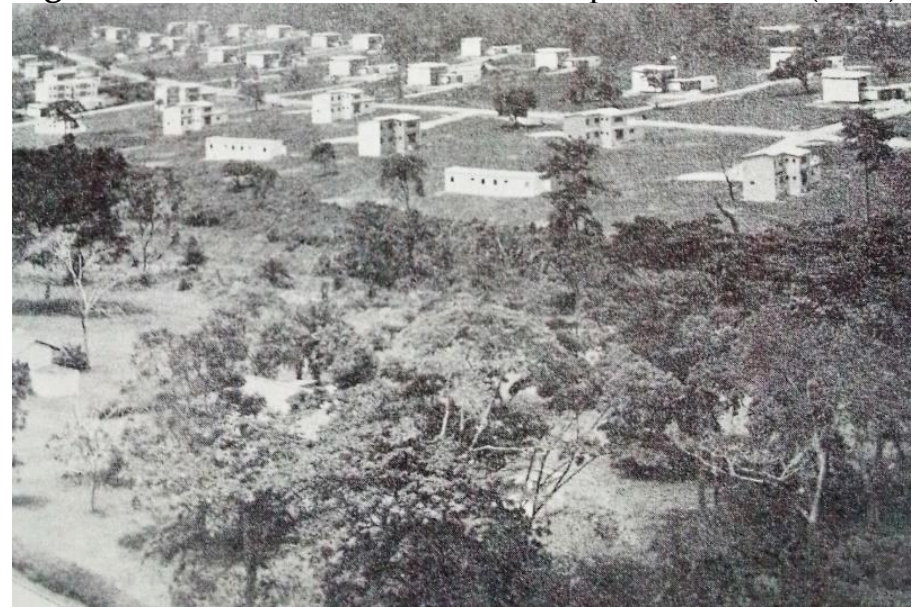

Figure 4: Aerial view of Residential Area (1951).

The Campus is identified with a group of modernist architectural buildings. James Cubitt designed the campus master plan. The campus was approximately 2.5 square miles. The Wiwi stream diagonally crosses the campus.

The campus buildings were divided into phases of five(5). First, the existing structures were temporal. Second, permanent buildings which include the main teaching areas, staff, and workers housing. Third and fourth, students and teaching areas such as the library, ceremonial building which includes the Great Hall were covered at the phase. The first 
building to be built on the campus was the school of engineering in 1956. It was built as part of a collaboration between British and Ghanaian governments on the development of universities. The building is tropical modern architecture which maximizes natural lighting and ventilation. The dominant concrete wing structure directs air into the building. The building is punctuated by a sequence of Y-shaped reinforced concrete beams with centers 30 feet wide. They also support cross ventilation and the collection of rainwater. The height of the building is 533 feet and 100 feet wide. It has clerestory window, a non-actinic glass, power-operated revolving, and travels around 135 degrees.

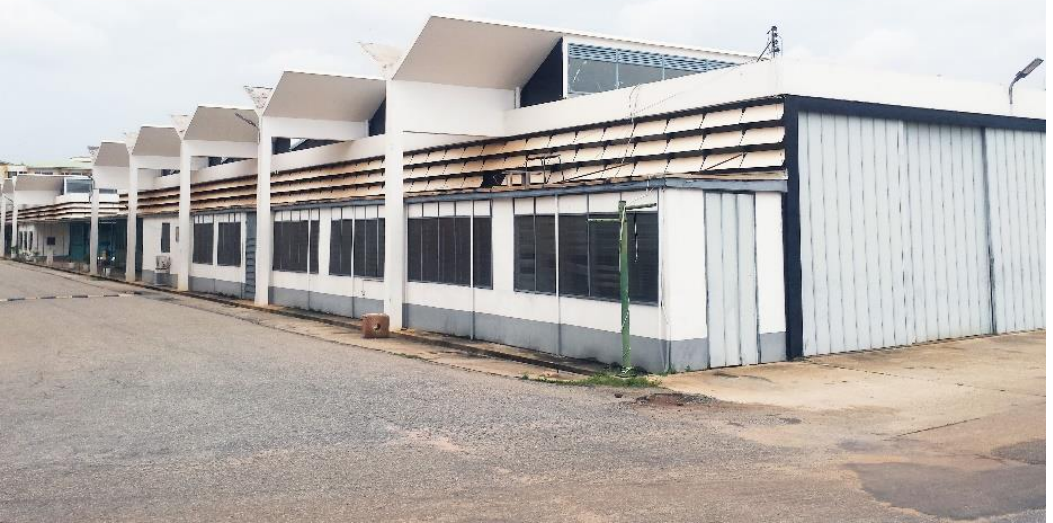

Figure 5: KNUST, School of Engineering (1956), James Cubitt \& Partners.

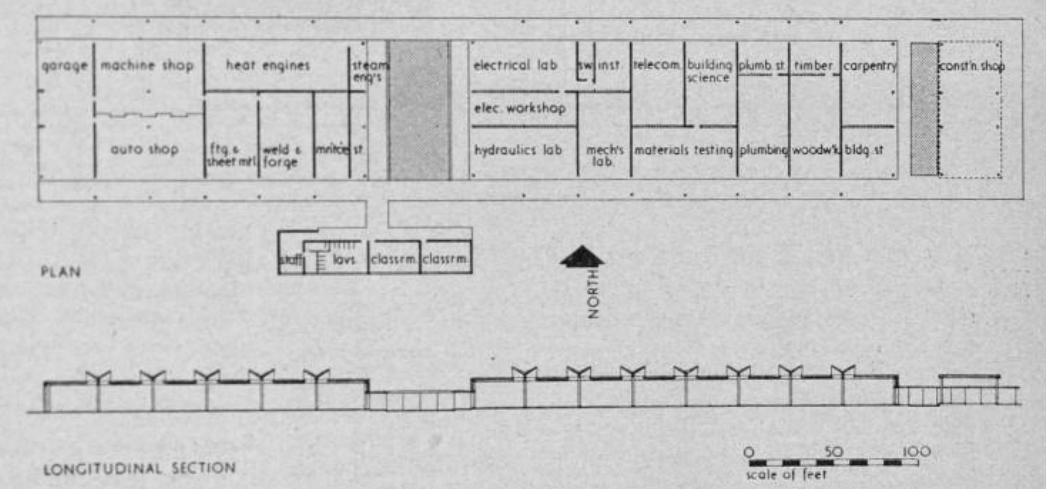

Figure 6: Plan and Section of KNUST Workshop Block College of Technology.

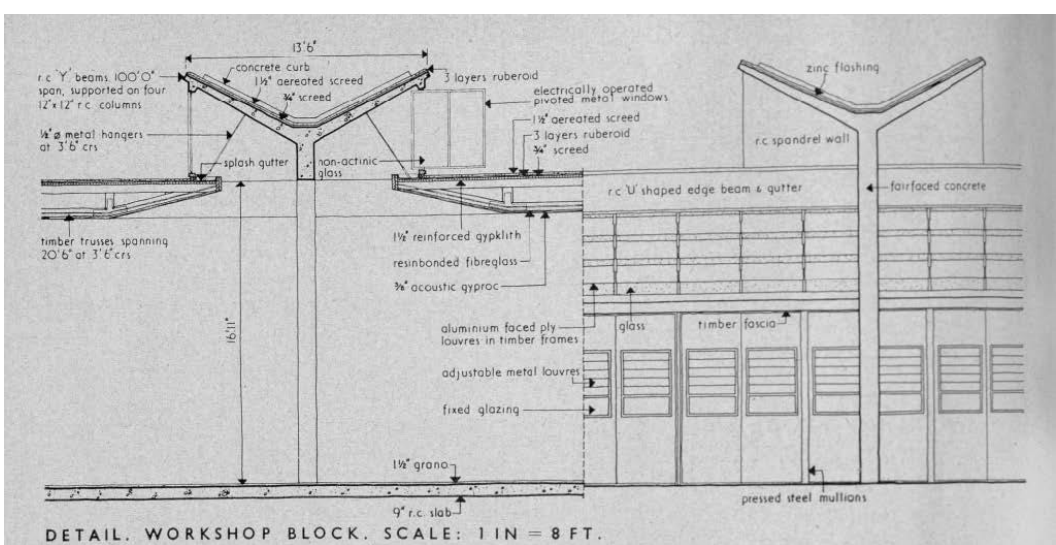

Figure 7: Section diagram of the Y-structural features in the engineering building. 
The Great Hall, an iconic building on the campus was built by the English architects Gerlach and Gillies-Reyburn between 1964 and 1967. The building is designed with a modernist architectural style mixed with colourful paintings on walls and staircases. The Great Hall makes use of natural ventilation techniques to achieve thermal comfort. The massiveness of the concrete slabs that build horizontal and vertical lines contrasts with the almost airy interior spaces that are bright. The building is a multi-functional design that includes a library, theatre, chapel, and a great hall. It was positioned on an east-west axis to take full advantage of natural breezes while minimizing the heat from the harsh sunlight. It was designed to serve as a large assembly room with a seating capacity of 1,250 people on the ground floor with extra 350 seating in balcony seating. This building is linked by walking distances to an annex, a reception area with changing rooms, pantry facilities, and excellent campus views.

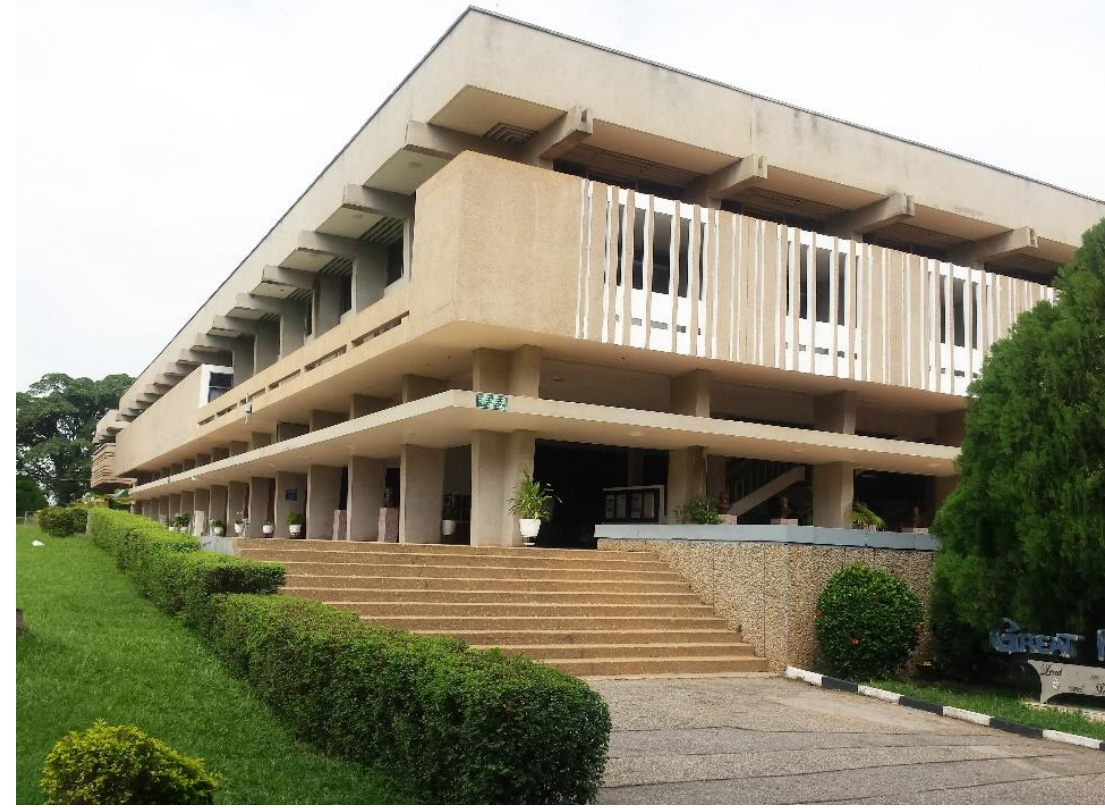

Figure 8: Exterior of Great Hall, KNUST (1964-1967), Gerlach and Gillies-Reyburn. (2020)

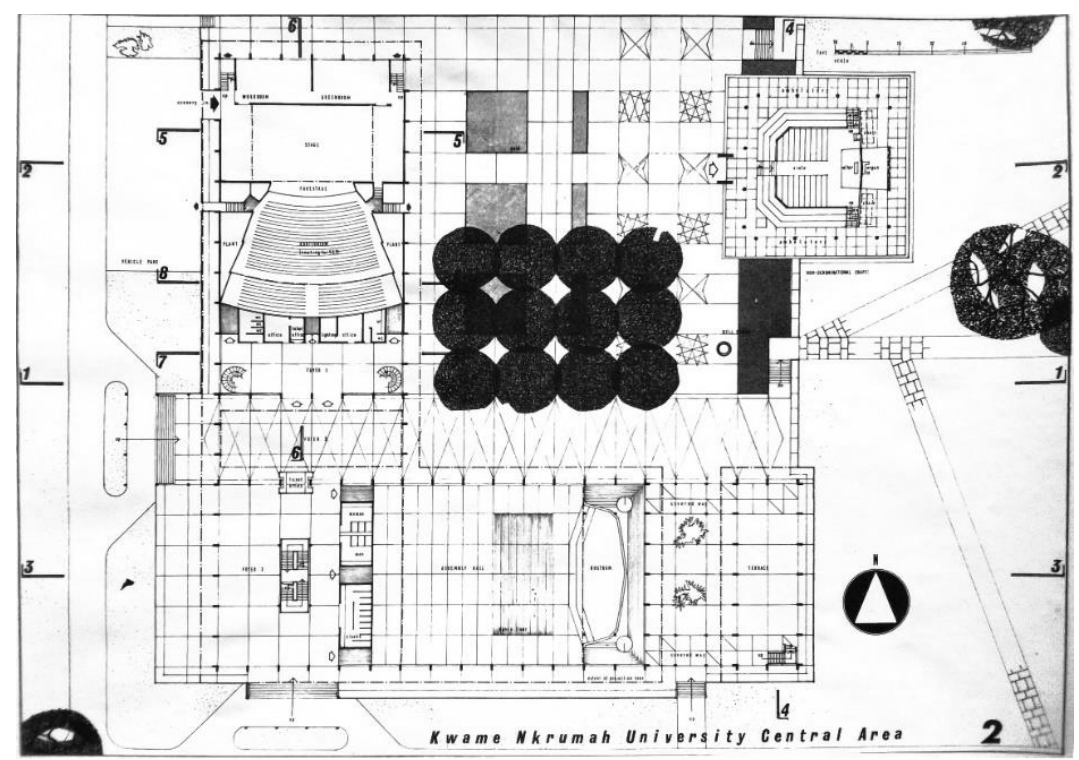

Figure 9: KNUST Great Hall, Ground Floor Plan. 


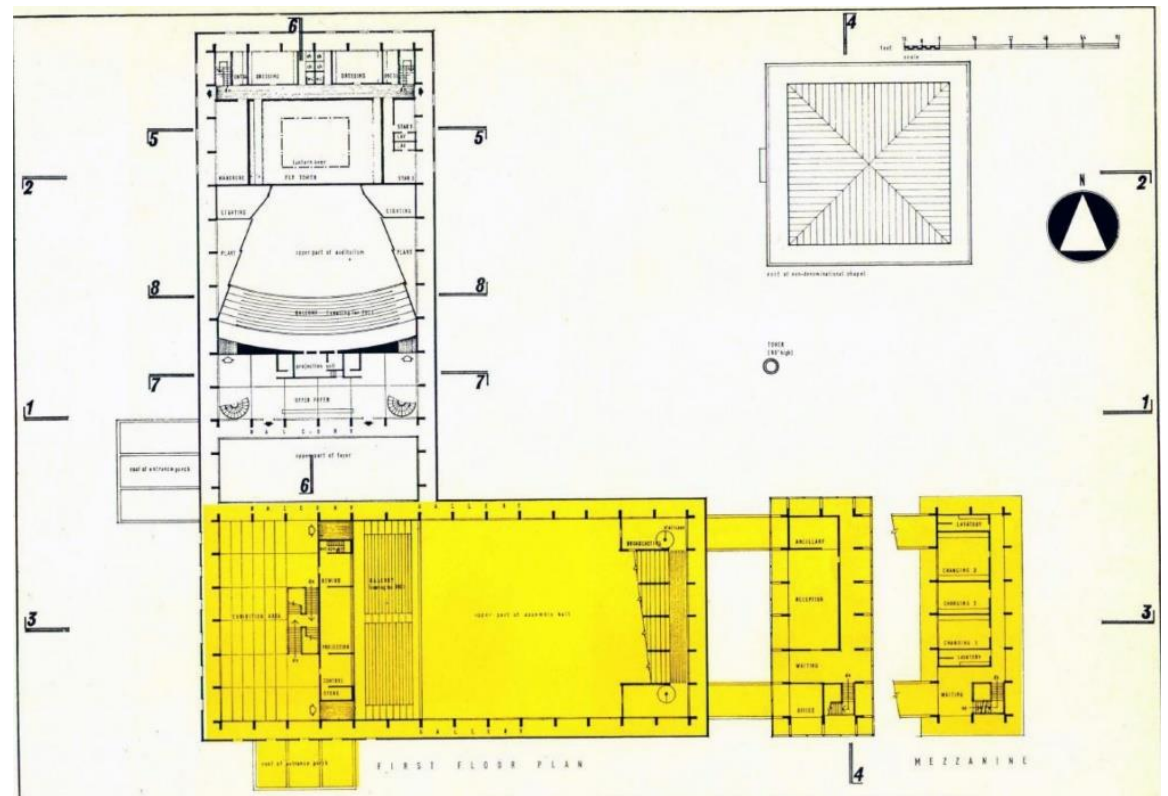

Figure 10: KNUST Great Hall, First Floor Plan.

The Unity Hall and the Africa Hall are two modern architectural landmark buildings on the campus. The buildings are high rise divided into individual units. The buildings are characterized by Le Corbusier's modernist principles. The buildings have Grand Pilotis with lifts and constructed in massive concrete with vertical and horizontal lines forming the structure. Both Unity Hall and Africa Hall were designed by Ghanaian architects. The former 1963 by Marasovic and John Owusu Addo and the latter 1964 to 1967 by Nikso Ciko and John Owusu Addo.

One of the earliest powerful was arguably Unity Hall Architectural statements made by a Ghanaian architect about modernism.

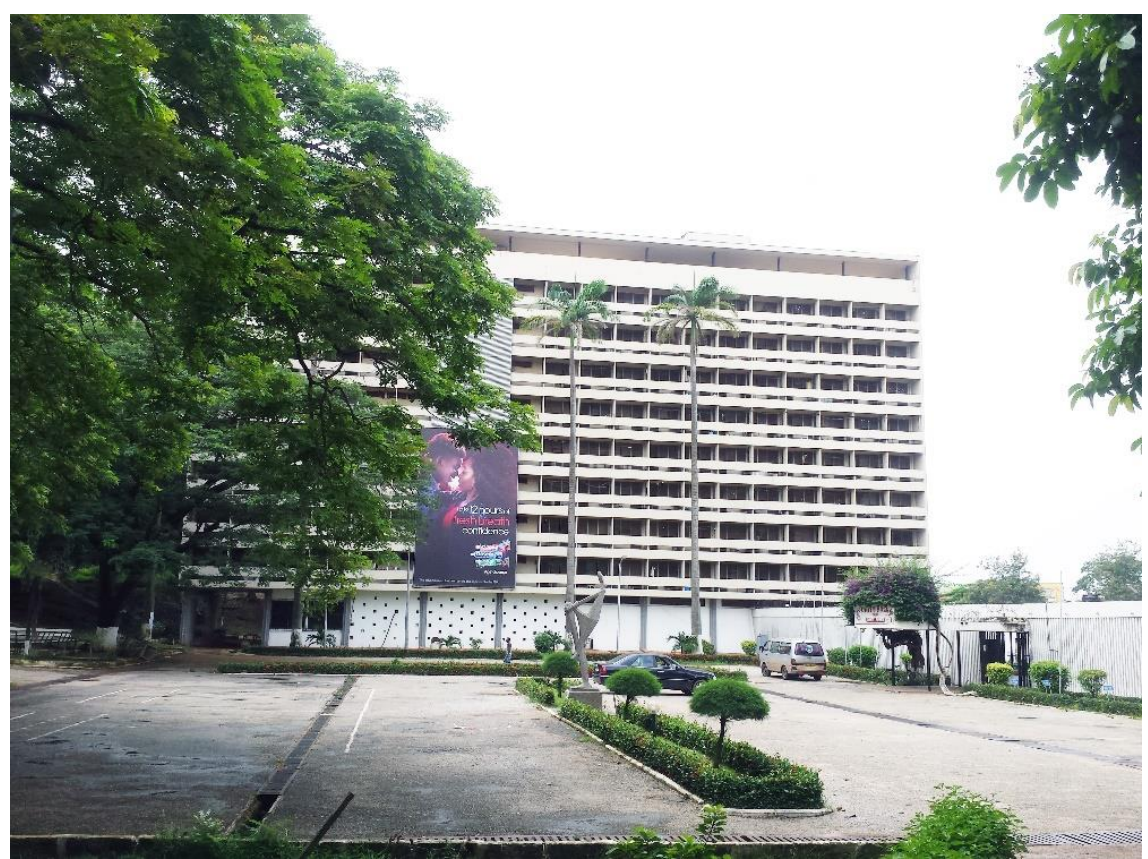

Figure 11: Unity Hall, KNUST, (1964-1967), Marasovic, and John Owusu Addo. .(2020) 


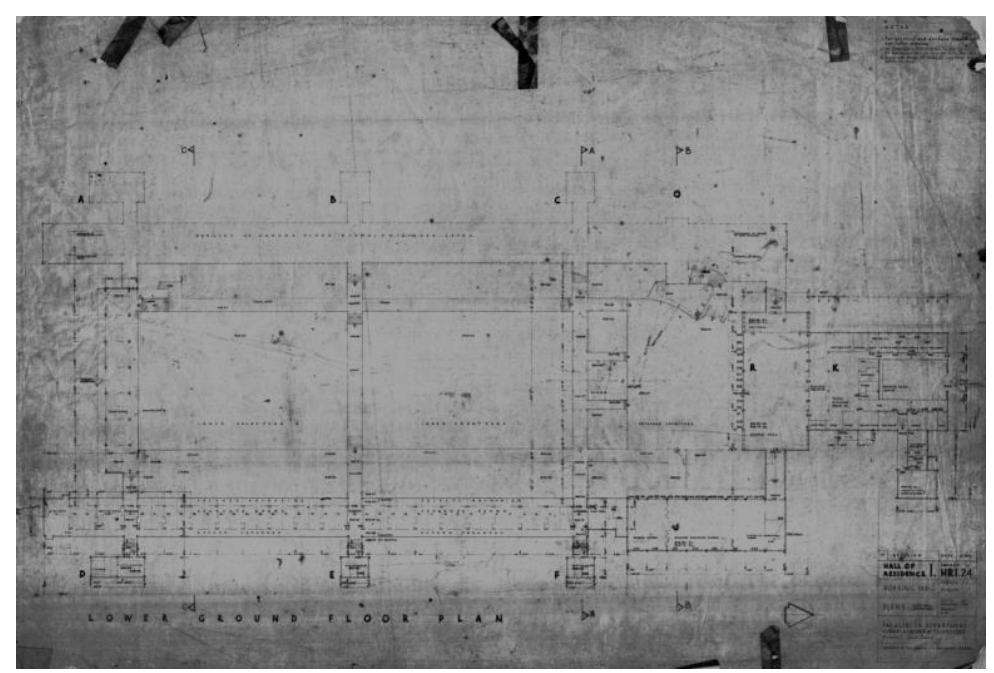

Figure 12: KNUST Unity Hall, Lower Ground Floor Plan. (1964-1967)

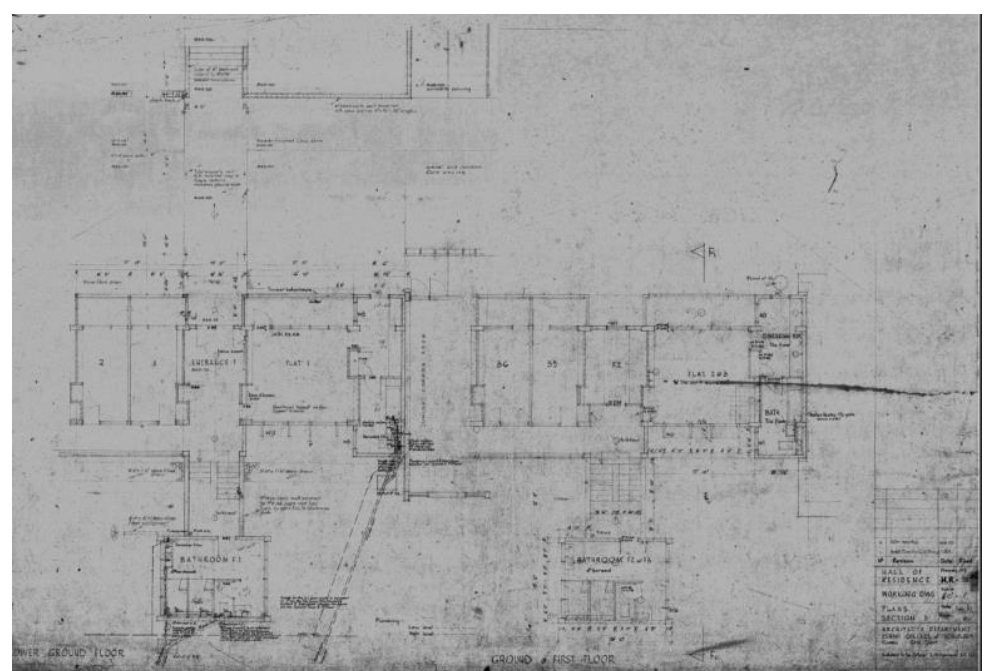

Figure 13: KNUST Unity Hall, Ground First Floor Plan, (1964-1967)

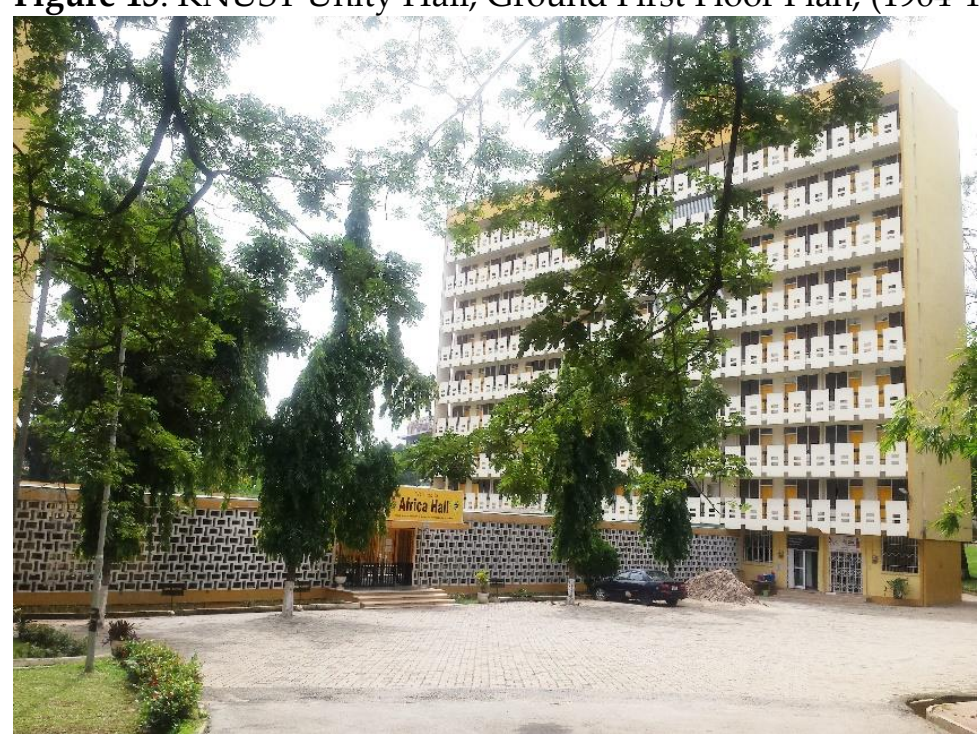

Figure 14: Africa Hall,(1964-1967), Nikso Ciko, and John Owusu Addo.(2020)

\subsubsection{Identity and character}

The campus is distinguished by its intriguing and striking modern architectural style on the campus. The naturally beautiful landscape creates a beautiful stimulating environment for a comfortable living. 
Majority of the buildings on the KNUST campus are painted a yellowish cream colour and light and dark grey colours. Most of the buildings are Compound and a longHorizontal typologies oriented north-south in relation to the Solar Path. The dominant roof typologies are Gable and Parapet. Wooden framed glass pivoted and louver window are the dominant window types.

The Campus Landscape creates a character and unifies the overall Built Environment of the Campus. This further defines boundaries access and circulation patterns and routes. The campus is also characterized by its exceptional dual carriage road leading to the Campus Core and a Sculpture. The Campus Entrance Gate adds Visual Character and Identity to the Campus by its unique welcoming design.
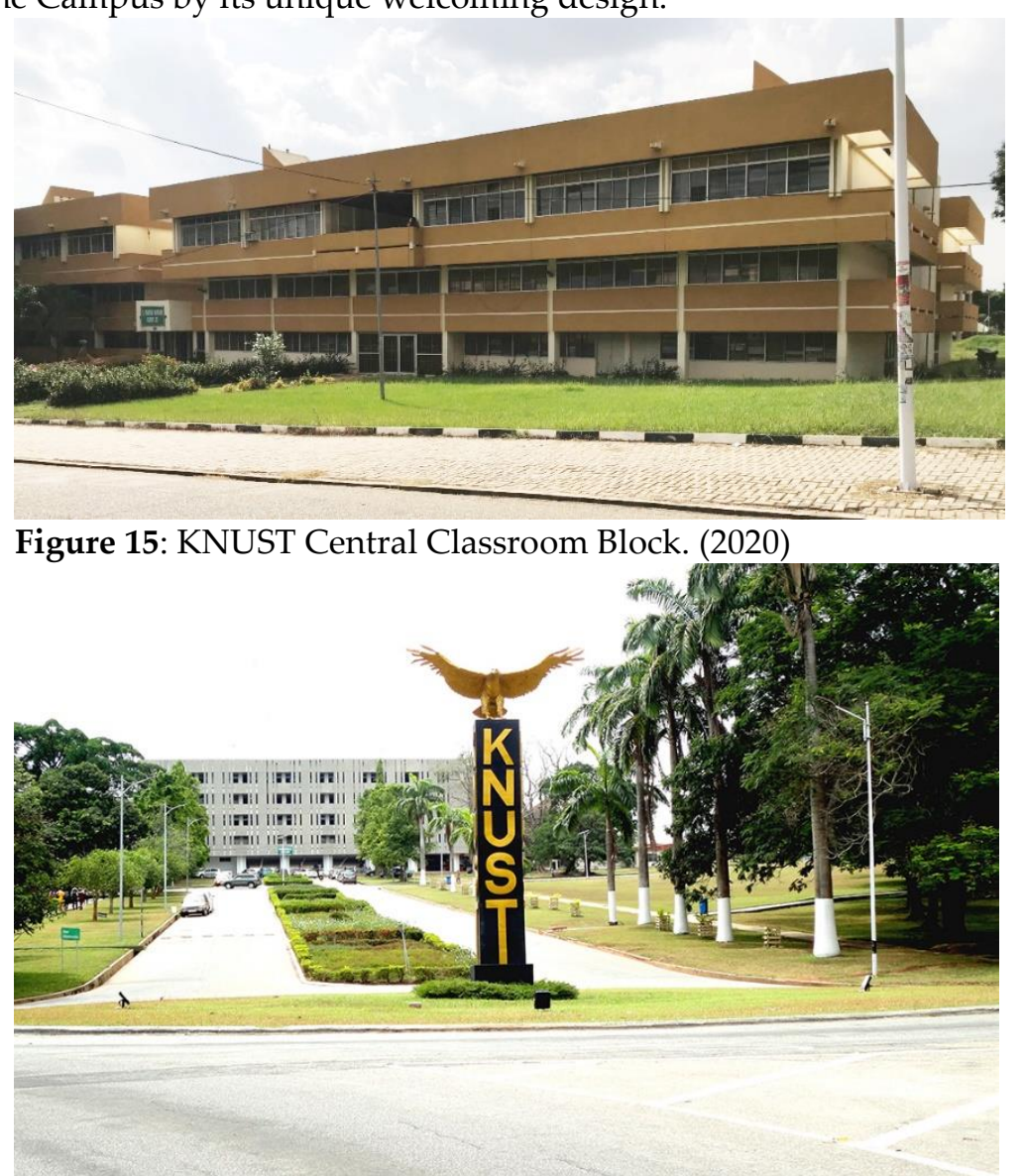

Figure 16: KNUST Dual Carriage road. (2020)

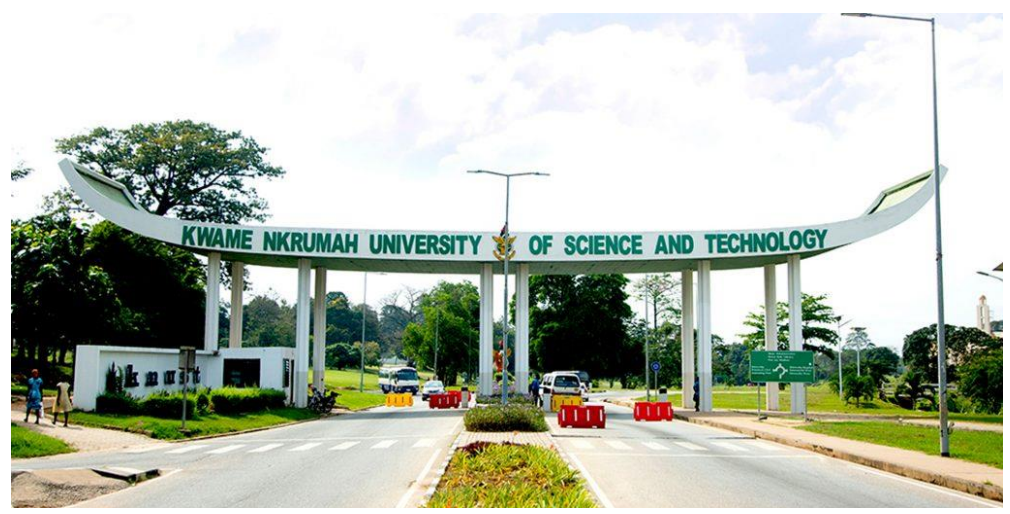

Figure 17: KNUST Entrance gate. (Author, 2020)

\subsubsection{Site Zoning, Landuse and Master Plan}

In the phase of developing the Campus Plan of KNUST, a number of land-use requirements where identified. These included land dedicated to main teaching areas, halls 
of residence and dining room, staff housing, labourers' housing, power station, assembly hall, and chapel.

THE PAST

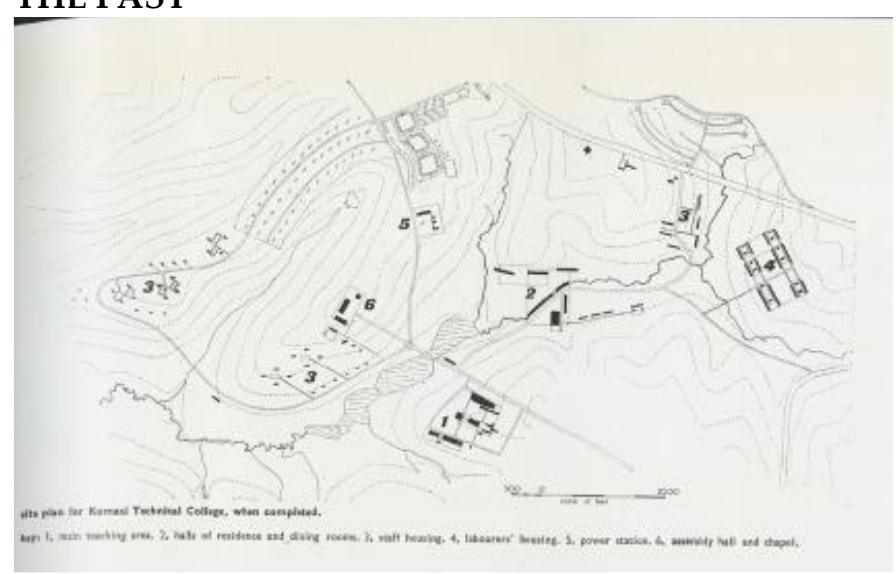

Figure 18: KNUST Master Plan (1956), James Cubitt. PRESENT

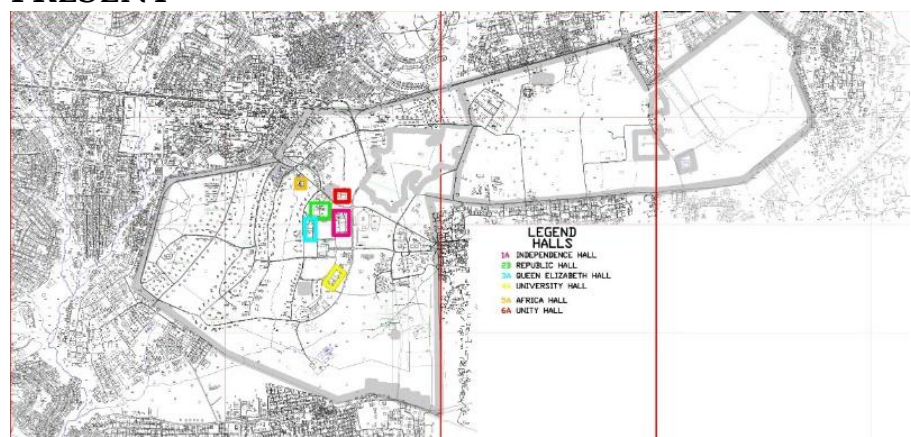

Figure 19: KNUST Master Plan (2020).

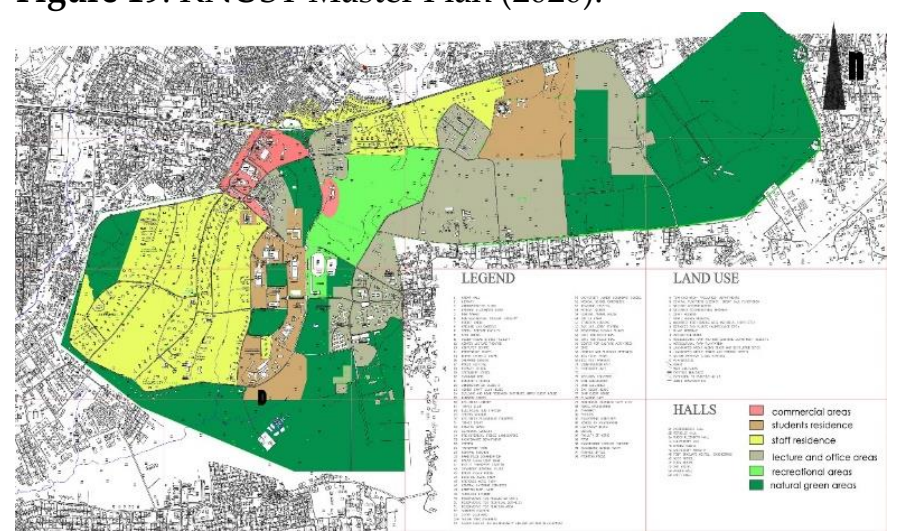

Figure 20: KNUST Land Use Map (2020)

The present land-use of KNUST campus has included numerous facilities and uses such as increased in classroom and lecture halls, offices, students' housing, agriculture and farmlands, recreation, parks and gardens, sewage disposal plant, public transport station, horticulture lands, staff quarters, bus and lorry station, non-residential student facilities, etc.

\subsubsection{The Campus Core}

KNUST campus core has been developed in proximity to the halls of residence and a functional distance from the main teaching areas. The core has periodically developed and yet maintained the character of the old existing campus. From accompanying drawings, it takes a distance of ten to fifteen minutes to walk from the main academic teaching areas to the campus core area. Further buildings from the campus core have led to the creation of new paths by the students or users. 


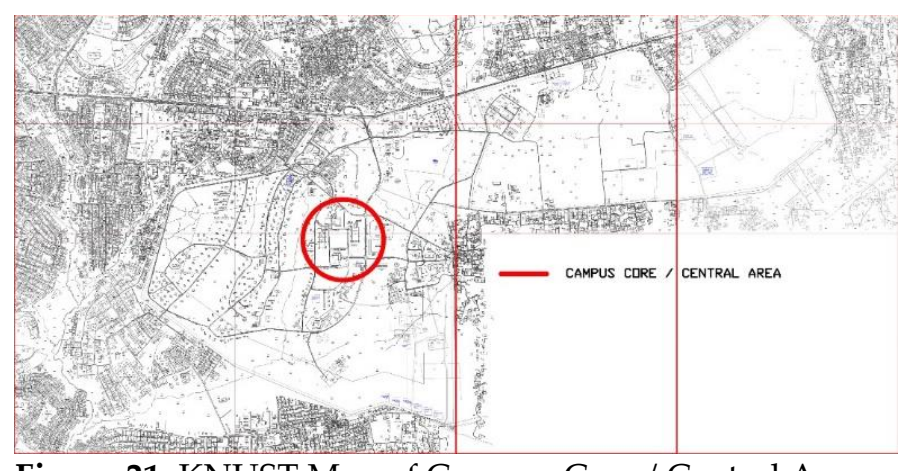

Figure 21: KNUST Map of Campus Core / Central Area.

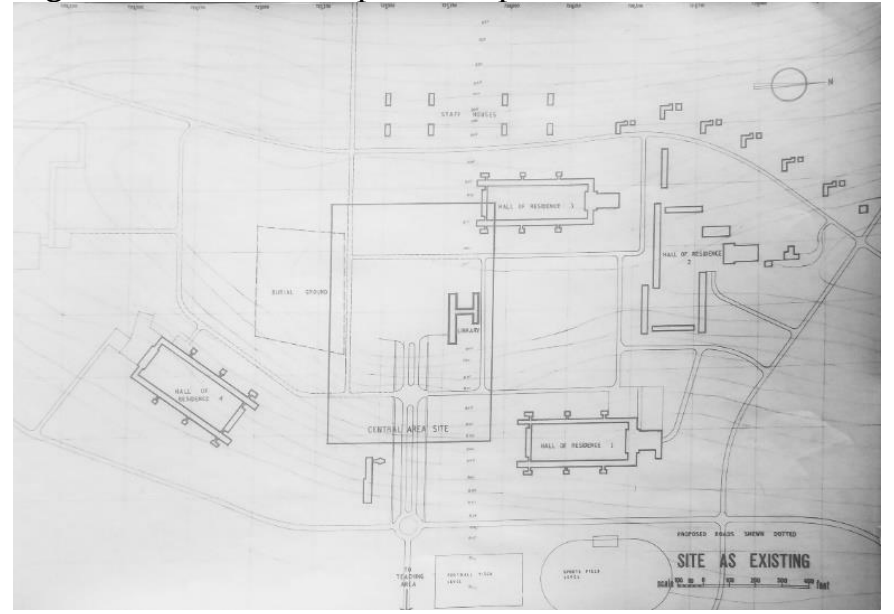

Figure 22: KNUST Campus Core / Area (1960-61)

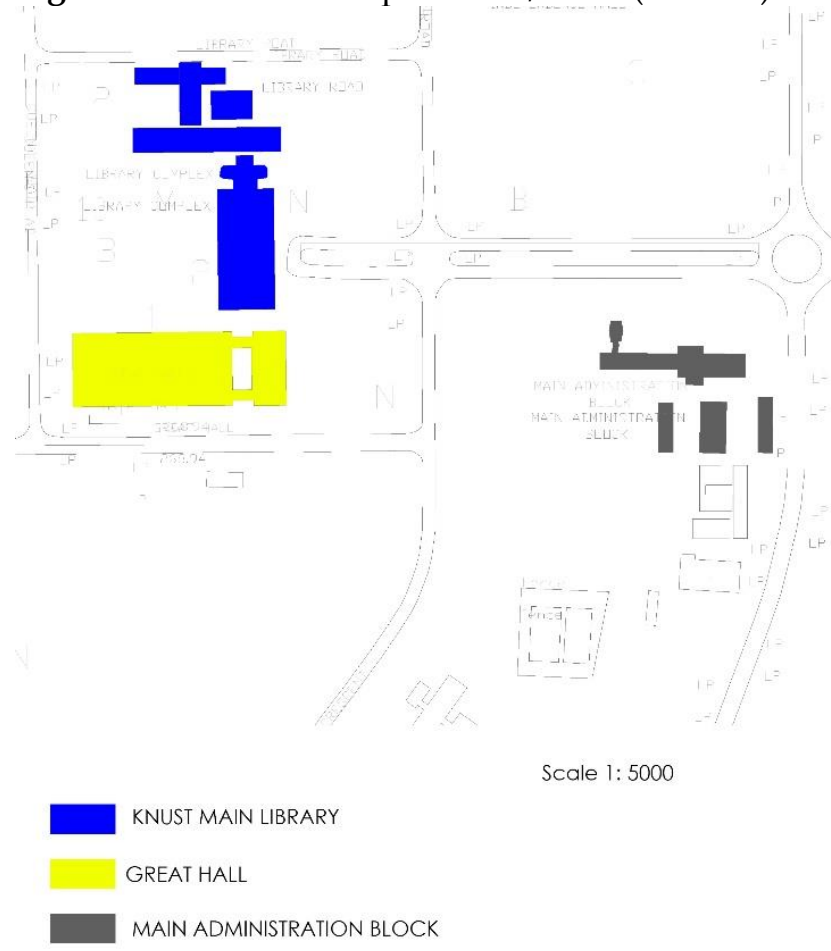

Figure 23: KNUST Campus Core / Area (2020).

The site selected for the campus core area is on a high ground ridge running northsouth, bounded by the Main Library on the north and about 400 feet away on the south. East and West, the terrain falls moderately steeply to an established slope with a carriageway approach and, respectively, to rugged, naturally contoured terrain. 


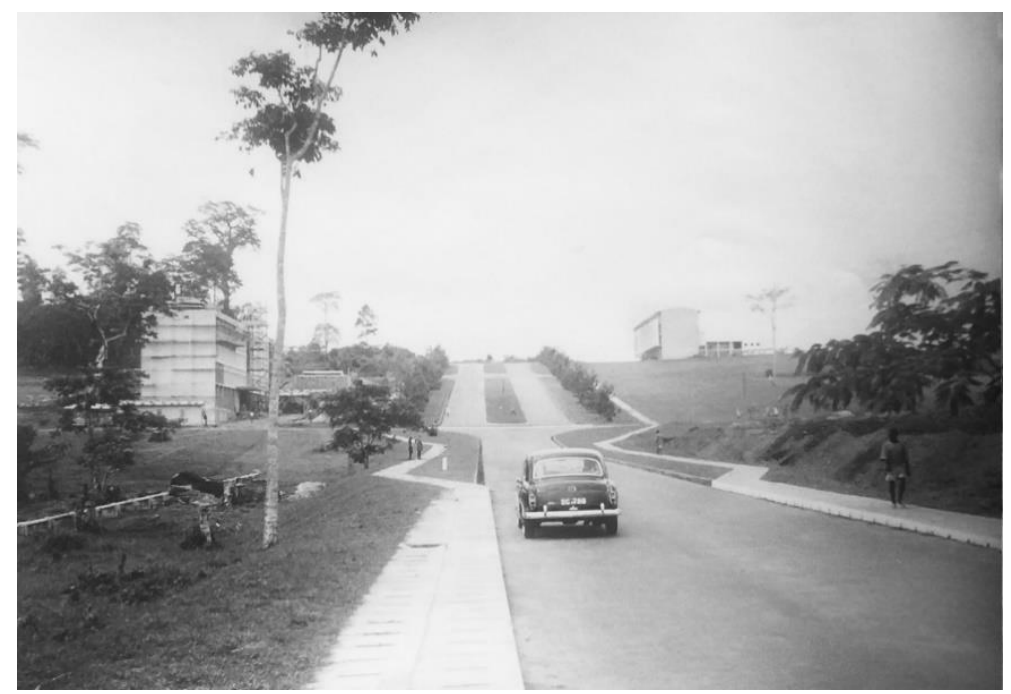

Figure 24: View from KNUST dual Carriageway (Pioneering Period)

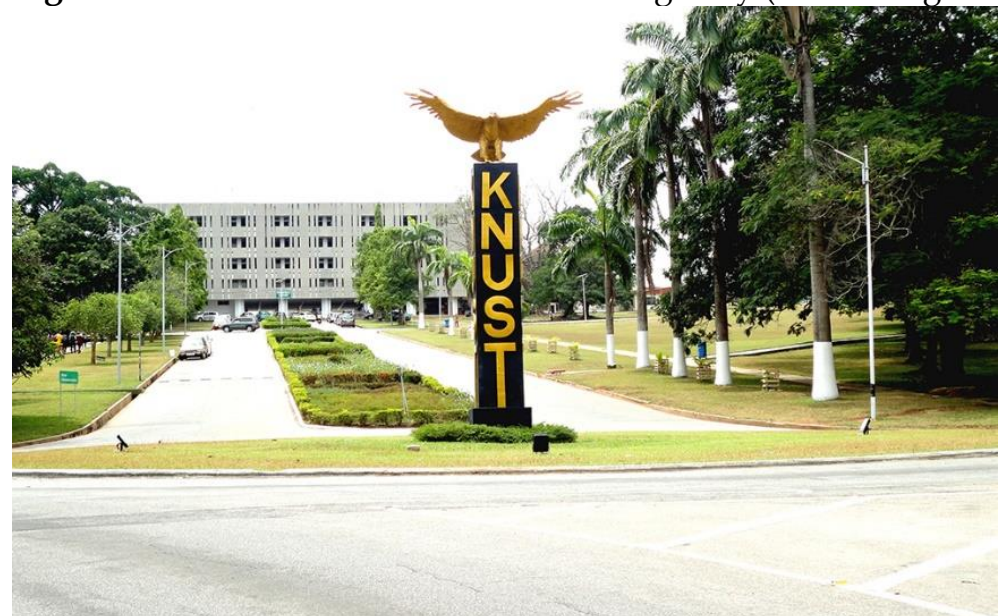

Figure 25: View from KNUST dual Carriageway ( 2020)

The library is a four-story small-scale building effectively design and situated eastwest across the ridge 's crown with around one pilotis on one-third of the western end. Large forest trees and dense undergrowth cover the burial ground on which restrictions on buildings were imposed.

The dual carriageway, consisting of 20 feet wide lanes, climbs the hill straight to the top and is flanked by avenue trees and footpaths that are partially developed. The lower end finishes in a roundabout at the university's main entrance road.

Between the roundabout and in-direct lane with the dual carriageway, a path continues down the hill and over the Wiwi River into the Teaching Area, about half a mile from the site. The new Administration building is situated by the roundabout and within this area. Residential Students Halls occupy the north and south slope of the building. The buildings are long, low-rise buildings and are placed informally and well integrated into the countryside.

The buildings including the Library form the 'focus' of the University Complex and are designed as a pedestrian-oriented design with limited vehicle traffic within a formally defined area. The Core Area is ideally positioned on the 'Site' near to the Teaching Areas, the Administration Building and the Student Halls of Residence.

The resolution of the upward surge of the approach road from the west was a preliminary consideration. One way to achieve this was by positioning the dominant element on the axis to absorb the motion. Another way was to redirect and absorb, 'the movement' into the landscape. 


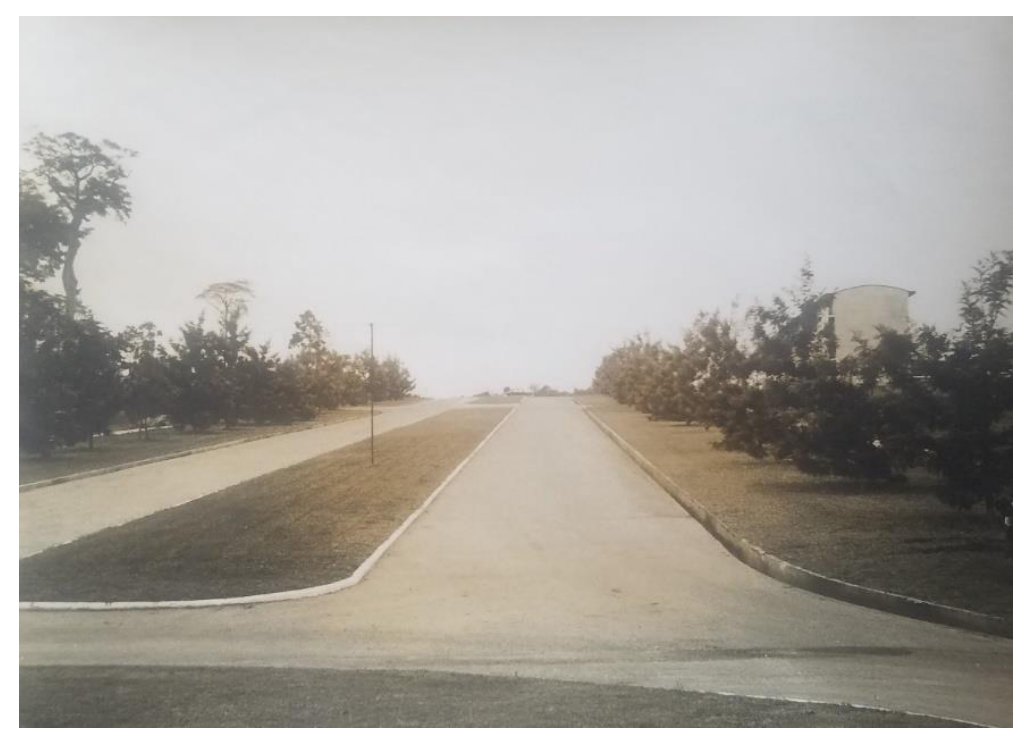

Figure 26: View from KNUST dual Carriageway (Pioneering Period)

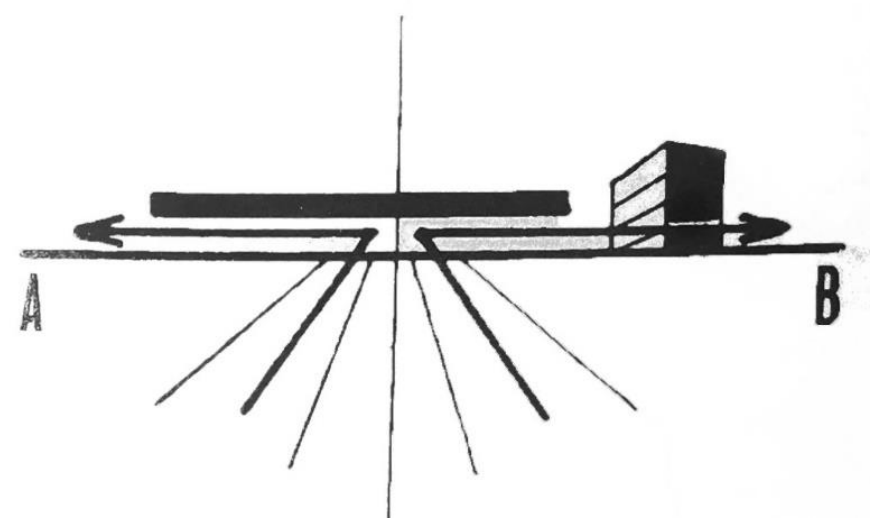

Figure 27: View from KNUST dual Carriageway (Preliminary Sketch)

This was done by arranging for the main massing of the building group to be in balance with such a change of direction.

From the figure it is clear that no emphasis was put on A - B. The new element was put back from the observer skyline to prevent the bulk of buildings from diminishing.

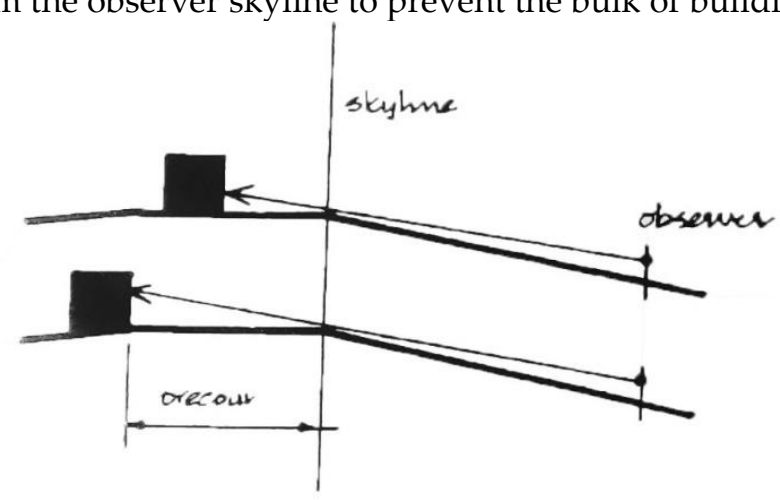

Figure 28: View from dual Carriageway (Preliminary Sketch)

From the aspect of the plan, the forecourt is the distance effectively to the skyline, thus, if the building was positioned further or too far, the forecourt would have reduced. 


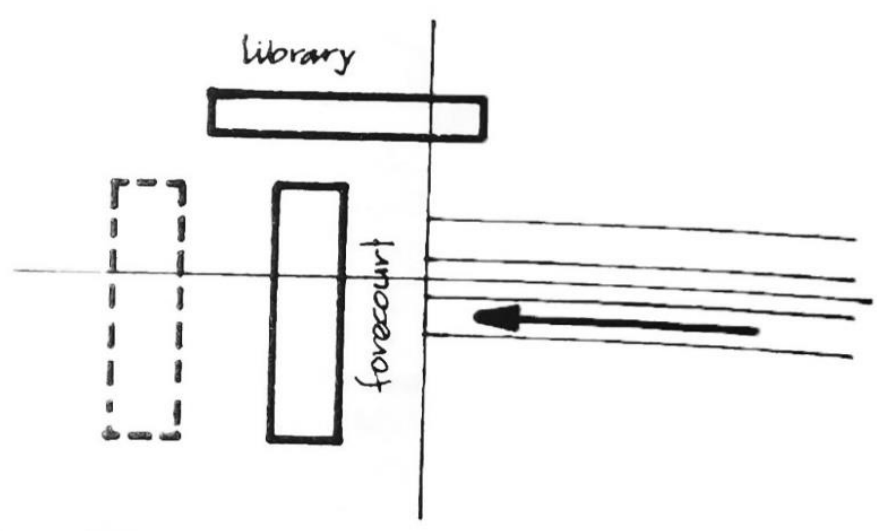

Figure 29: View from dual Carriageway (Preliminary Sketch)

A compromise was made for a suitable forecourt allowing for a fair line site from the observer approaching simultaneously from the dual carriageway. Viewed from the teaching area, the long low configuration described tends to unite and emphasize the buildings for the existing development along the ridge by converging road lines into a focal point.

\subsection{Case 2, UG Campus Planning and Architecture}

University of Ghana, Ghana's biggest and the premium university was founded as the Gold Coast University College, by Ordinance On 11 August 1948 with a view of providing and promoting the education, learning, and research. The campus covers an area of 99.3 hectares and located about 12 kilometers $(7.5 \mathrm{mi})$ north-east of the city center in the district of Accra Metropolis, in the Greater Accra region of Ghana with latitude $5^{\circ} 38^{\prime} 59.99^{\prime} \mathrm{N}$, and longitude is $0^{\circ} 10^{\prime} 60.00^{\prime} \mathrm{E}$.

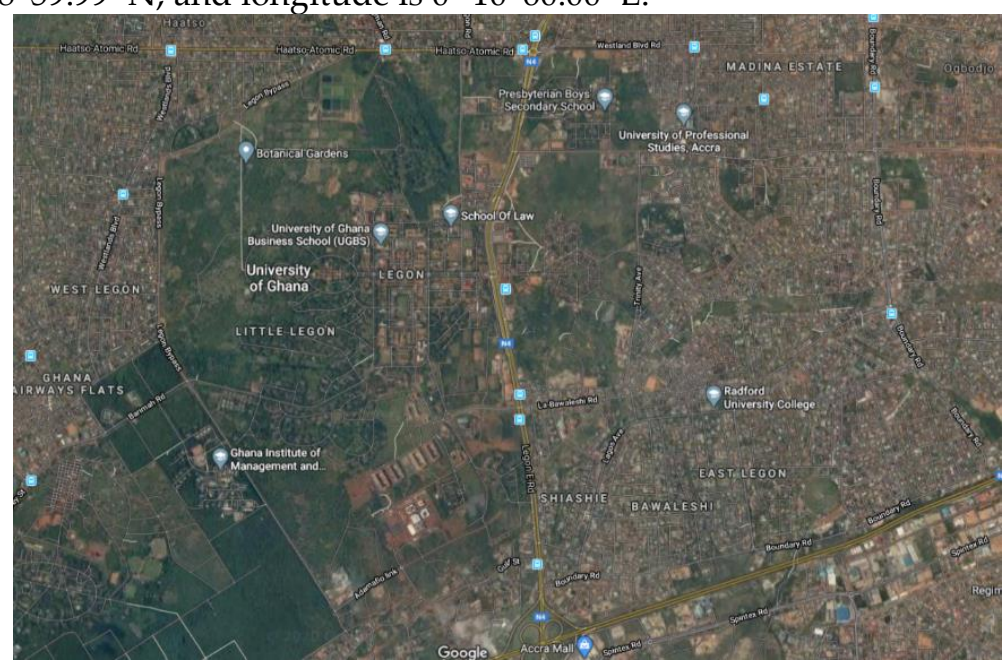

Figure 30: Satellite Map of the University of Ghana.

As a university, it has a vision of being an 'Intensive Institution of World-Class Research' in the next decade. And its mission is to create an enabling environment that makes national and global development increasingly relevant through cutting-edge research and high-quality teaching and learning.

\subsubsection{Establishment of the University}

In 1948, The University of Ghana was established as the Gold Coast University College, on the Asquith Commission recommendation on Higher Education in the British colonies at the period. Among other things, the Asquith Commission, formed in 1943 to examine higher education, proposed the creation of University Colleges in conjunction 
with the University of London. That has been followed by a number of different Commissions in various regions. The West African Commission was headed by the Rt. Hon. with Walter Elliot. The Elliot Commission published a majority report recommending the establishment of two Gold Coast University Colleges (Ghana), and Nigeria, and a minority report that held that only one university college for all of British West Africa was feasible. The British Government initially accepted the Elliot Commission's minority report and decided to establish a University College for British West Africa as a whole at Ibadan, Nigeria. But that recommendation could not be accepted by Gold Coast people. Led by the late Dr. J.B. Danquah, the scholar and politician, admonished the government of Gold Coast to notify the British Government that the Gold Coast could support a college of universities. Therefore, the British Government decision was reviewed and admitted to establish Gold Coast University College.

The Gold Coast University College was established by Ordinance on 11 August 1948 to provide and encourage university education, learning, and science. The late Mr. David Mowbray Balme was its first Principal. Mr. Balme had a farsighted mind, brave and dedicated to fostering scholarship. By its vision, its industry, and its uniqueness intentionally, he built up a college and laid the foundations for a sound University that is now a source of pride. In his ten years as Principal, he created an institution whose keynote was to live in a community of scholars with dignity. One of several Asquith Commission's recommendations was that the British government should put up an Inter-Universities Council to advise on all matters associated with higher education in the new British Colonies. In an advisory capacity, the Inter-Universities Council served the new Gold Coast University College but approved all academic appointments.

In the 1960-61 academic year, the College Council requested the legislative Government of Ghana to institute the University College into a university with the power to award its degrees. An International Commission was appointed by the Government to examine the problem. On that Commission's recommendations, the University of Ghana was established on 1 October 1961 (Act 79) by Parliament Act. Dr. Kwame Nkrumah, then President of the Republic of Ghana, became the University's first Chancellor, with Nana Kobina Nketsia IV, BLitt DPhil (Oxon), Essikado's Omanhene as the (Interim) Vice-Chancellor.

\subsubsection{Site and Buildings}

The University College of Ghana was formed in 1948 in temporary buildings in the Western Compound of Achimota a school and college. A site of five and a half miles at Legon, three miles from Achimota, was allocated by the Government for the development of permanent buildings of the College.

Buildings began in 1950 and at the date of Independence, three Halls for students, accommodating 540 students in all, was built and plans for other buildings were far advanced. Legon Hall, the first to be built, located at the school center near the West Africa's biggest library, hence the Balme Library and now the University's Premier Building. Two main housing areas for senior staff was developed.

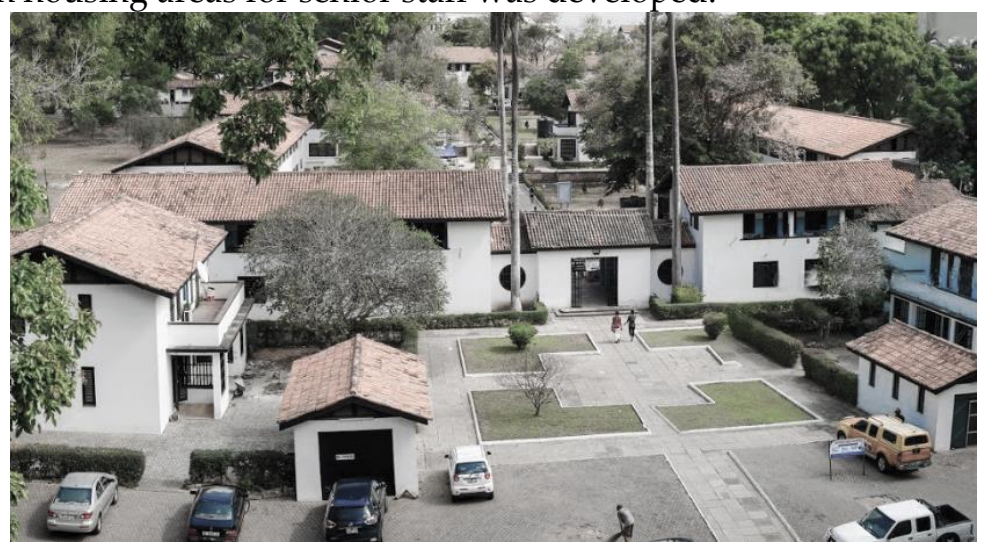

Figure 31: Aerial View of UG Legon Hall. 
Since the date, the following major buildings were also completed; Great Hall and Administration Buildings, together with a Council Chamber block containing offices for the Principal and the Provost, a Women's Hall for 82 students, Library, Faculty of Arts, buildings for the Departments of Chemistry, Physics, Botany, Zoology, Economics, Geology, Geography, Archaeology, Agriculture, Sociology, Education, Phonetic, and the Institute of Extra-Mural Studies, a University Hospital with 20 beds, and a Police Station.

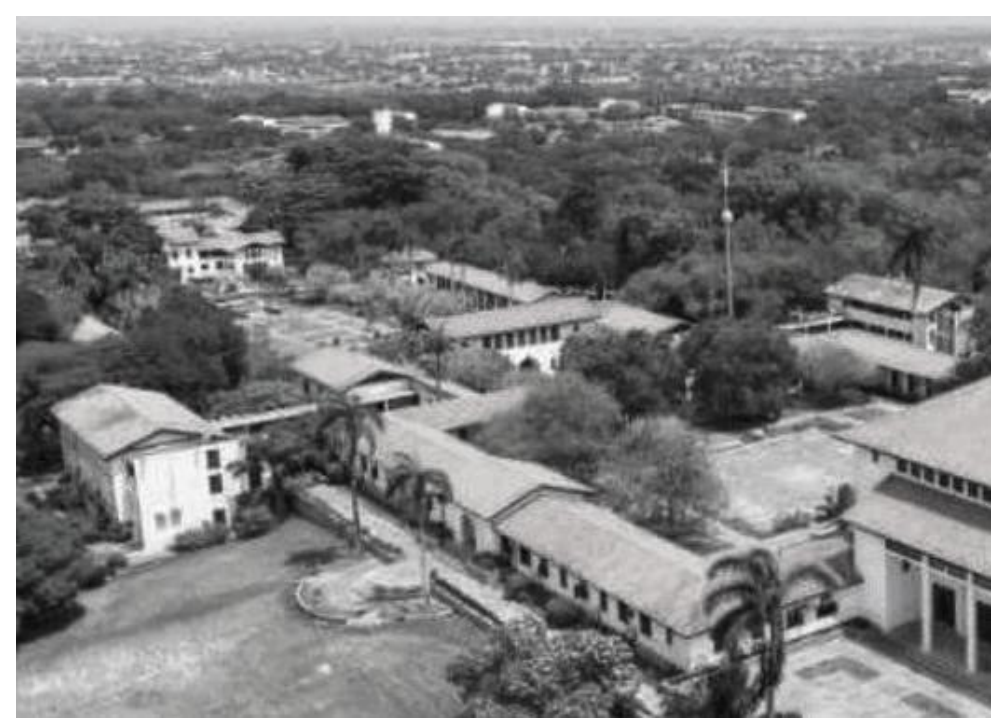

Figure 32: Aerial View of the UG Administration Buildings.

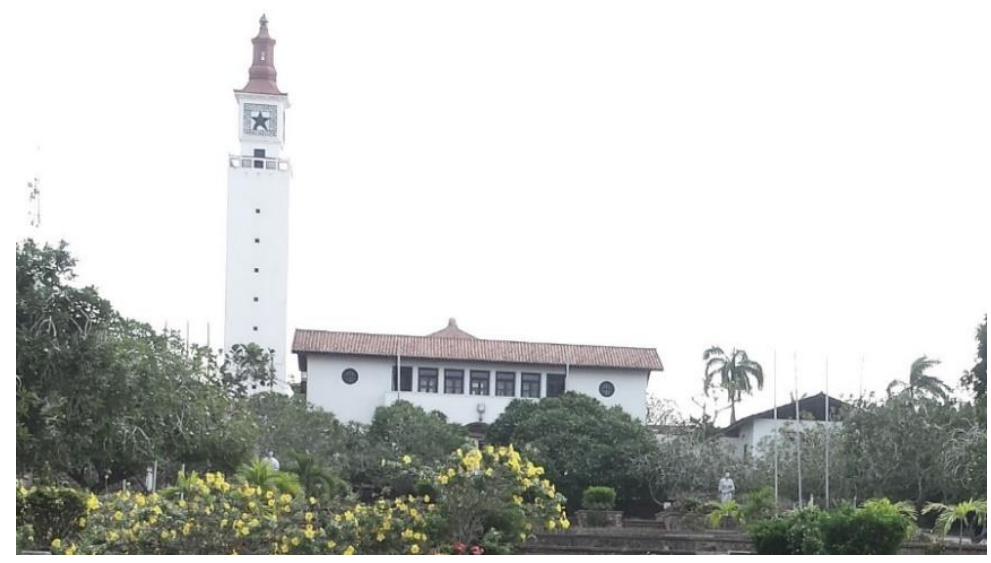

Figure 33: Exterior View of the UG Great Hall.

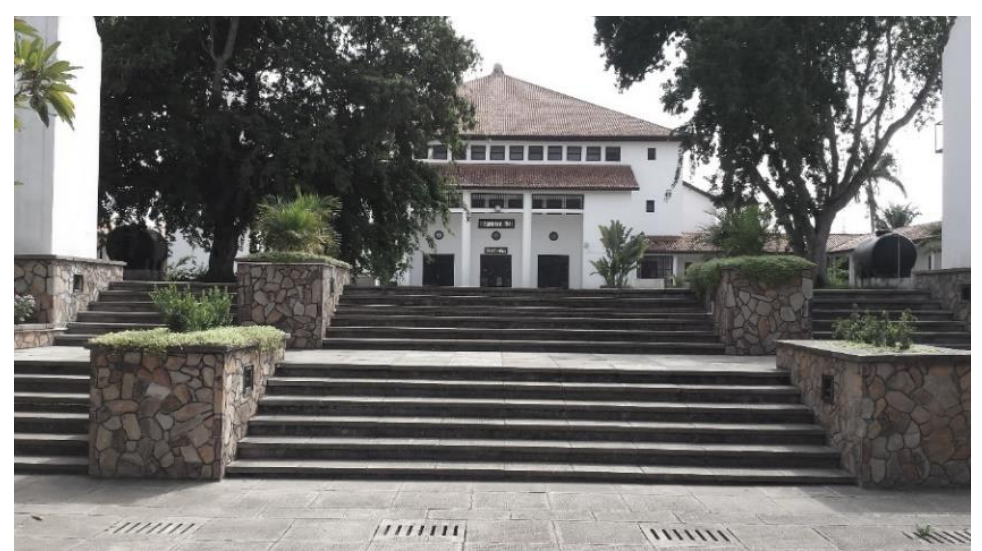

Figure 34: Exterior View of the UG Great Hall. 
Also, the housing program progressed steadily and 90 houses for senior staff were erected. A staff Village, roads and services, and houses were built by local contractors.

Future developments under the Second Development Plan included a fifth Hall for 310 men students, a Roman Catholic Chapel, a Civil Engineering, Post-graduate Research Unit, and a new housing area was allocated for further 104 houses and included the Principal's Lodge.

When this phase of development was completed, residential accommodation and teaching facilities for over 1,000 students were put up together with housing for all senior staff and a proportion for the junior staff.

It was then proclaimed by a policy that, the university needed to expand and to accommodate a student population of at least 5,000 by the end of the decade. This involved a parallel expansion, thus, a pro-rata one. This implied that existing capacity increased. At that time, the existing campus through larger was functionally badly designed.

From an architectural perspective, the campus required the creation of a new campus designed to accommodate for purposes of teaching, research, lodging, and feeding - more than twice the number at present accommodated at Legon, with a parallel expansion of all existing services (workshops, sanitary and medical). This task was a vast and complex one, both functional and architectural. Between the existing accommodation and the new, there was then a need for redistribution of functions, to make possible the most efficient and economic use of all facilities. Thus, for instance, the building presently used as a library, 'the Balme Library' was located on the main University campus (Legon), it coordinates a large number of libraries proximity to a number of schools, institutes, faculties, departments, and the university residential halls, which most are independent. The library started in 1948 as the College Library and was then located at Achimota College, about eight kilometers from the current Legon campus. The Balme Library was extremely badly designed for its purpose at that time but meet quite well the different requirements of another purpose, thus, Institute of African Studies or other Faculty. In 1959, the College Library was named after David Mowbrary Balme, the first principal of the University College of the Gold Coast after moved to a new location on the Legon campus.

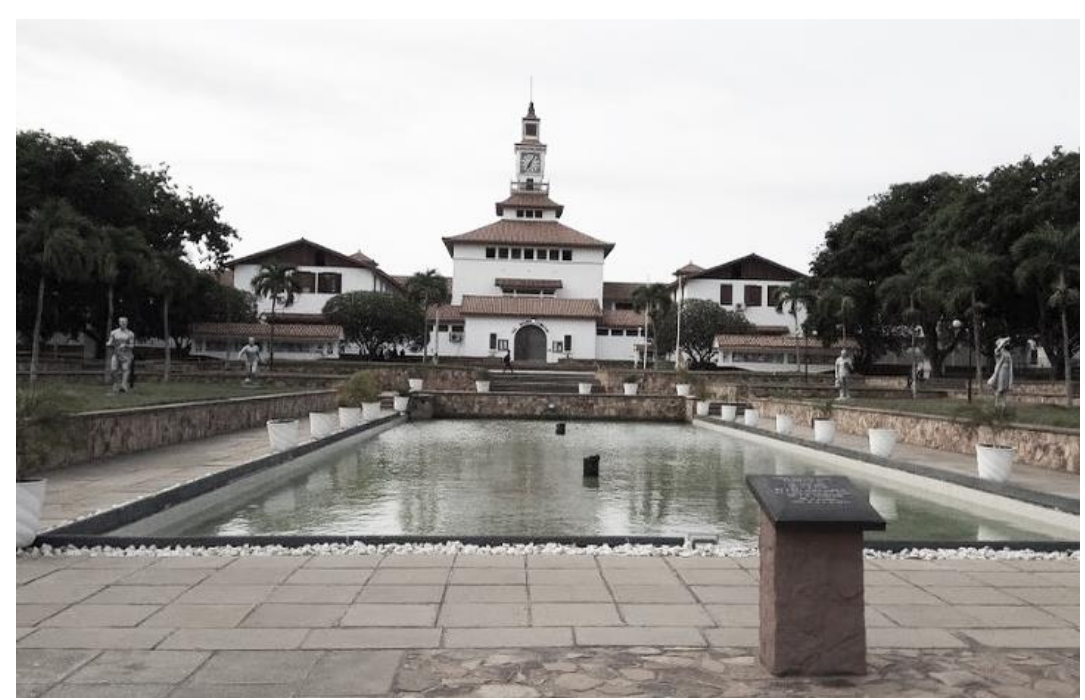

Figure 35: UG Balme Library and the Square. (2020) 


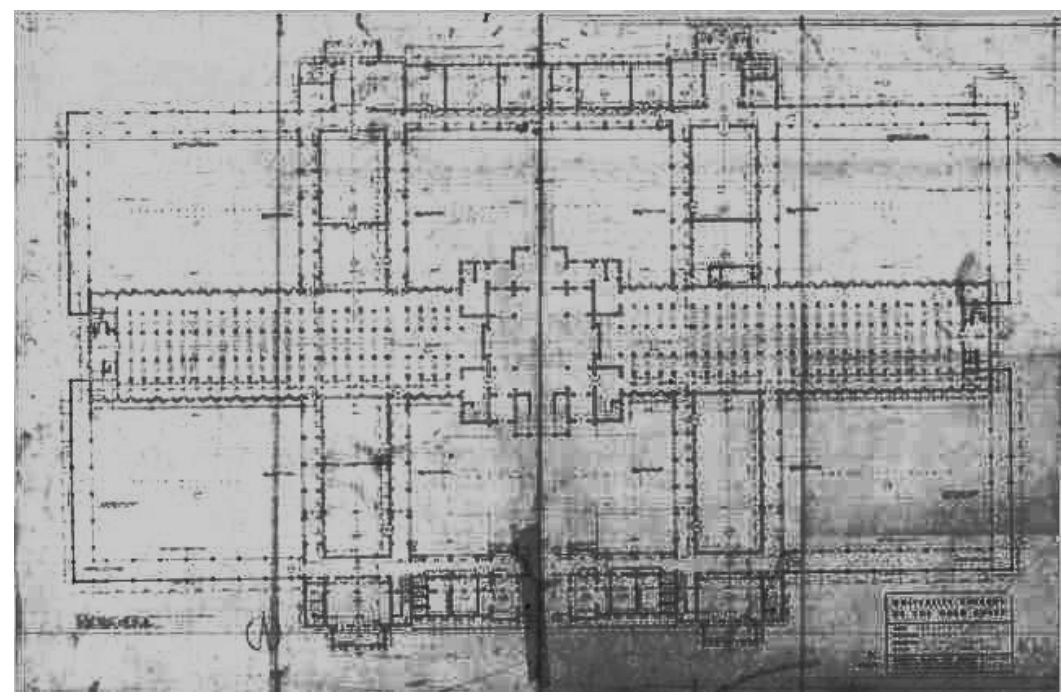

Figure 36: UG Balme Library Ground Floor Plan. (1959)

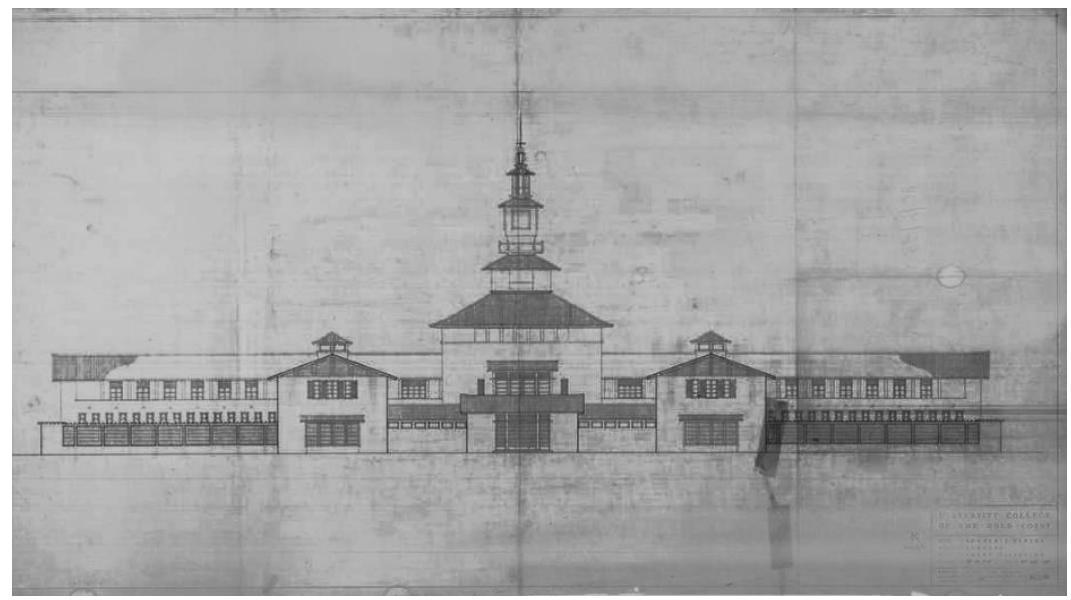

Figure 37: UG Balme Library Side Elevation. (1959)

A consultant from Israel, Michael Nadler, advised on a sloping site of north Legon and a part of the plain below set aside by the university Development Committee as a tentative site for new development. The site had an advantage because of its topography (the slope), possible for creating a new campus differing very sharply from the old and to be functional and economical but not depriving the old campus of its character. It was also intended to acquire additional lands mainly to the North and West of the present Campus, to give the Architects more freedom in siting the new buildings, as well as the Botanical and Zoological Gardens, Staff Quarters, Sports Grounds, etc.

A Master Plan for the development of the site was needed by the university for its expansion up to 1970. This was a clear and the greatest complex task and demanded the fullest extension of the world's leading Architects and Planners to create in Ghana, a new university campus using available resources with maximum efficiency, economy, and beauty to become one of the showpieces not only in Africa but of University architecture throughout the world.

The University Development Committee having this in mind decided after long discussions to proceeded an international competition. This competition was limited to foreign architects but was also opened to all architects practicing in Ghana. This was made known to the Ghana Association of Architects, thus, practicing architects at Accra, Kumasi, etc., will be able to compete and participate in the international competition. Out of 23 internationally renowned architects who participated in the competition, 7 were shortlisted and agreed to continue. These were the top professional architects in their 
countries. The best known of them was probably Oscar Niemeyer of Brazil amongst the other comparable standards. Three assessors, senior architects of great eminence, were chosen and agreed to serve and improved the programme. This procedure of an international competition was open to all architects in Ghana and was approved by Osagyefo at an interview with Nana Nketsia and the Vice-Chancellor. The procedure was confirmed by the secretariat of the Union Internationale des Architectes.

There came reliance on KNUST on the architectural services at Kumasi. KNUST's inability was noted, concerning a much smaller project in designing the Master Plan for Cape Coast University. In the event, the master plan was entrusted to a firm of Italian architects, Camtec. Most of the buildings were designed by foreign architects with only a few of the completed ones by a resident group of architects.

This did not mean that KNUST had no part to play in the University's development plan. Other architects and groups of architects had the opportunity to carry out both major and minor works (faculty buildings, hostels, students' union lecture rooms and laboratory blocks, etc.) within the Master Plan.

\subsubsection{Identity and Character}

Most buildings at Legon Campus are average three floors. The campus is characterized by tropical compound buildings and long horizontal buildings oriented in the northsouth axis concerning the Solar path. It has a Colonial Architectural Style with a majority of the buildings having a gable roof with a distinctive Red Clay Roofing Tiles. The major of the buildings are painted, White. This colour reflect more light and thus reduces heat.

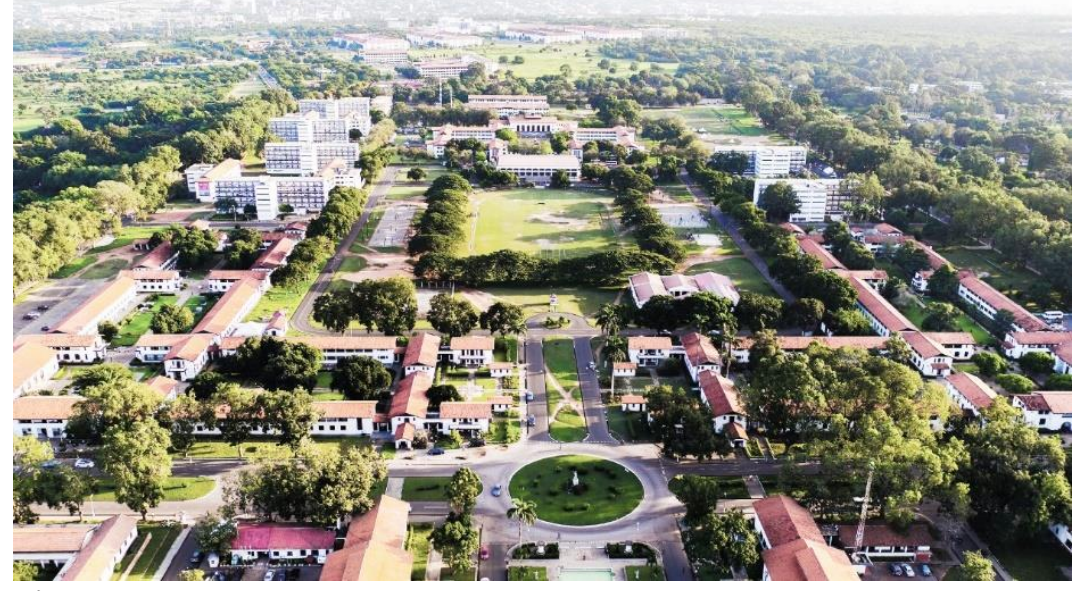

Figure 38: Aerial View of the UG Campus Buildings.

The Campus Landscape creates a distinctive Visual identity and harmonizes the Campus Built Environment. This also defines the circulation patterns, districts, spaces, and entries. The campus is also characterized by its unique Sculpture which also reflects the Ghanaian African Culture.

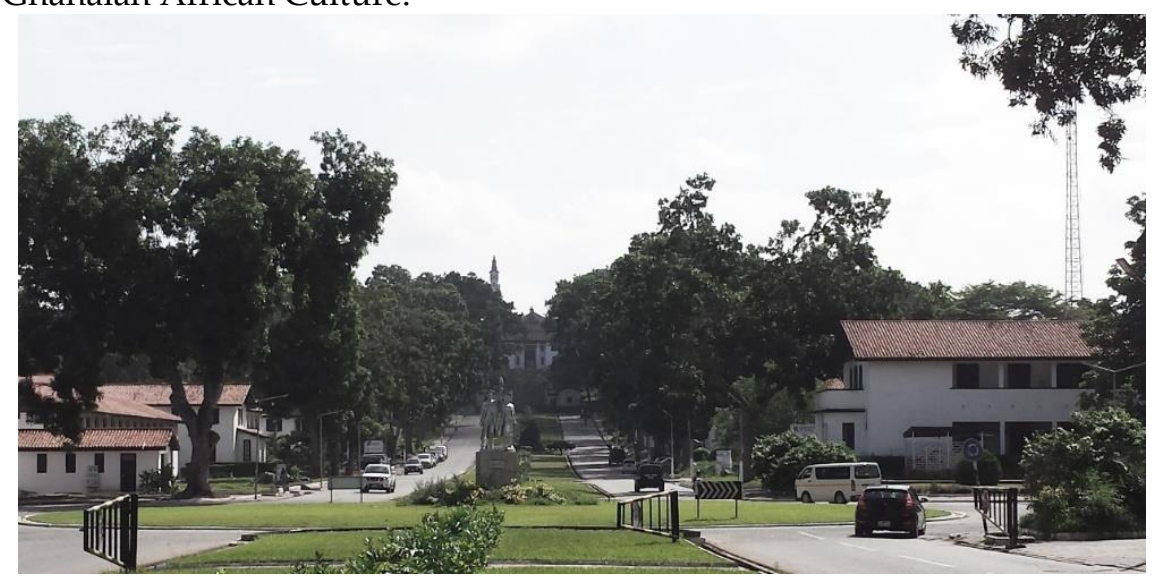

Figure 39: UG Dual Carriage Road.(2020) 


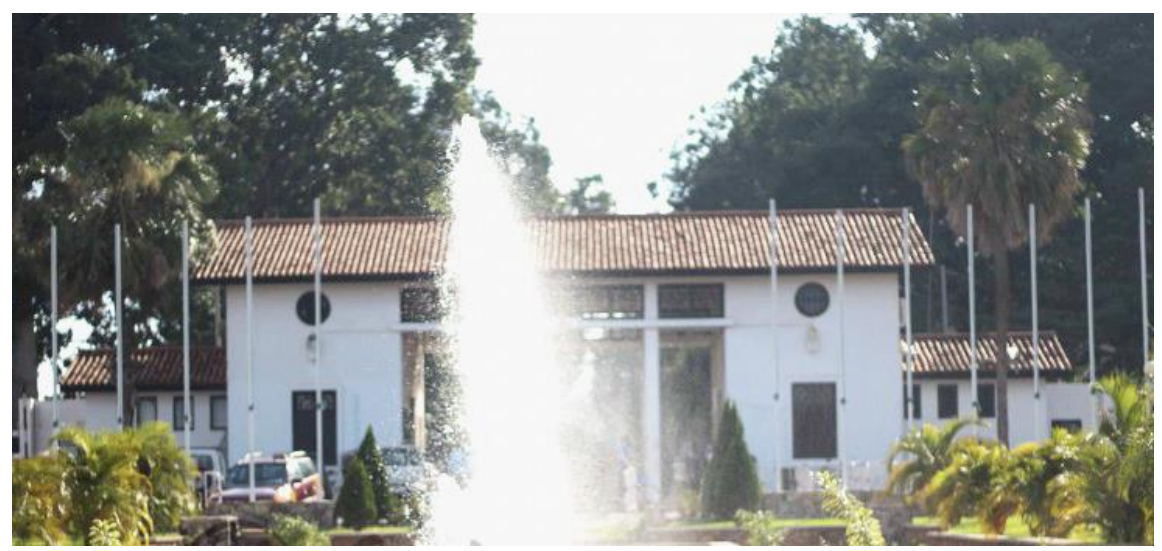

Figure 40: UG Entrance Gate. (2020)

The main access to the campus is characterized by its unique and welcoming entrance gate with a dual carriage road. This type of road also brings identity and character to the campus Core.

\subsubsection{Site Zoning, Land Use and Master Plan}

During the phase of the Legon Campus Plan Development, the plan included first, Halls of Residence, the College Library now referred to as the Balme Library, the Great Hall and Administration Buildings. Further development included an increase in Halls of Residence, a Chapel, Lecture Halls, Civil Engineering, Post Graduate Research Unit, and Principal Lodge.

With time, another building has evolved including expansion and increase in students' residential accommodation, staff housing, faculty buildings, commercial facilities such as a local branch of banks, café, bookshop, Botanical, and Zoological Gardens, etc.

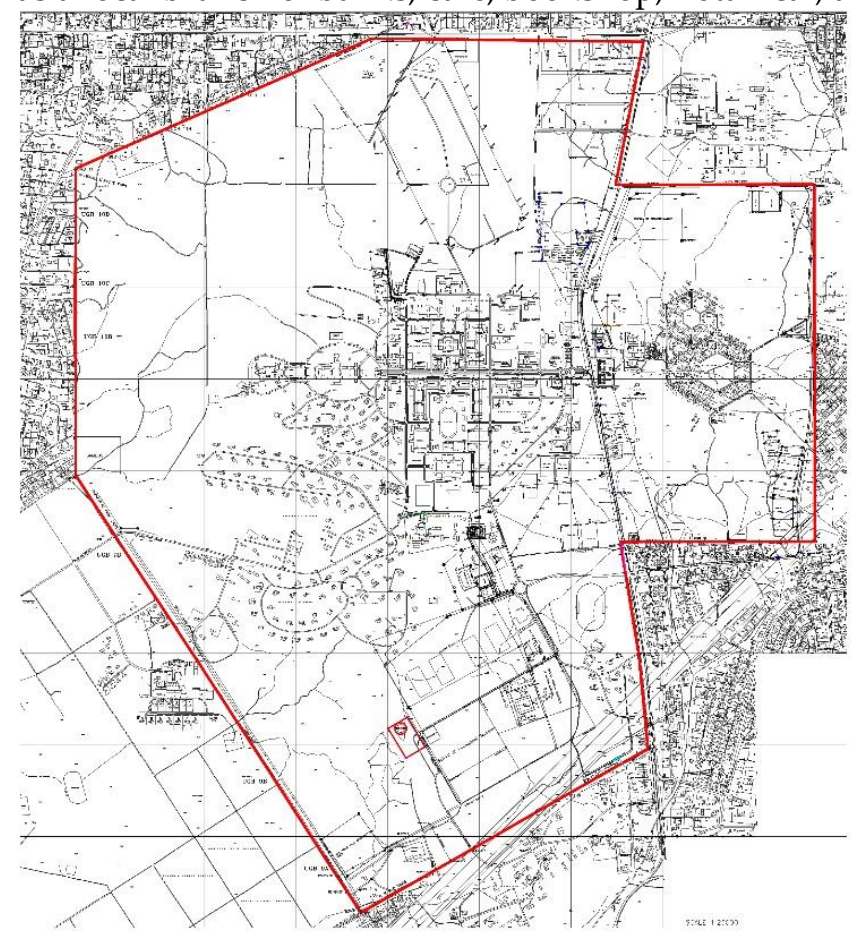

Figure 41: UG Master Plan. (2020) 


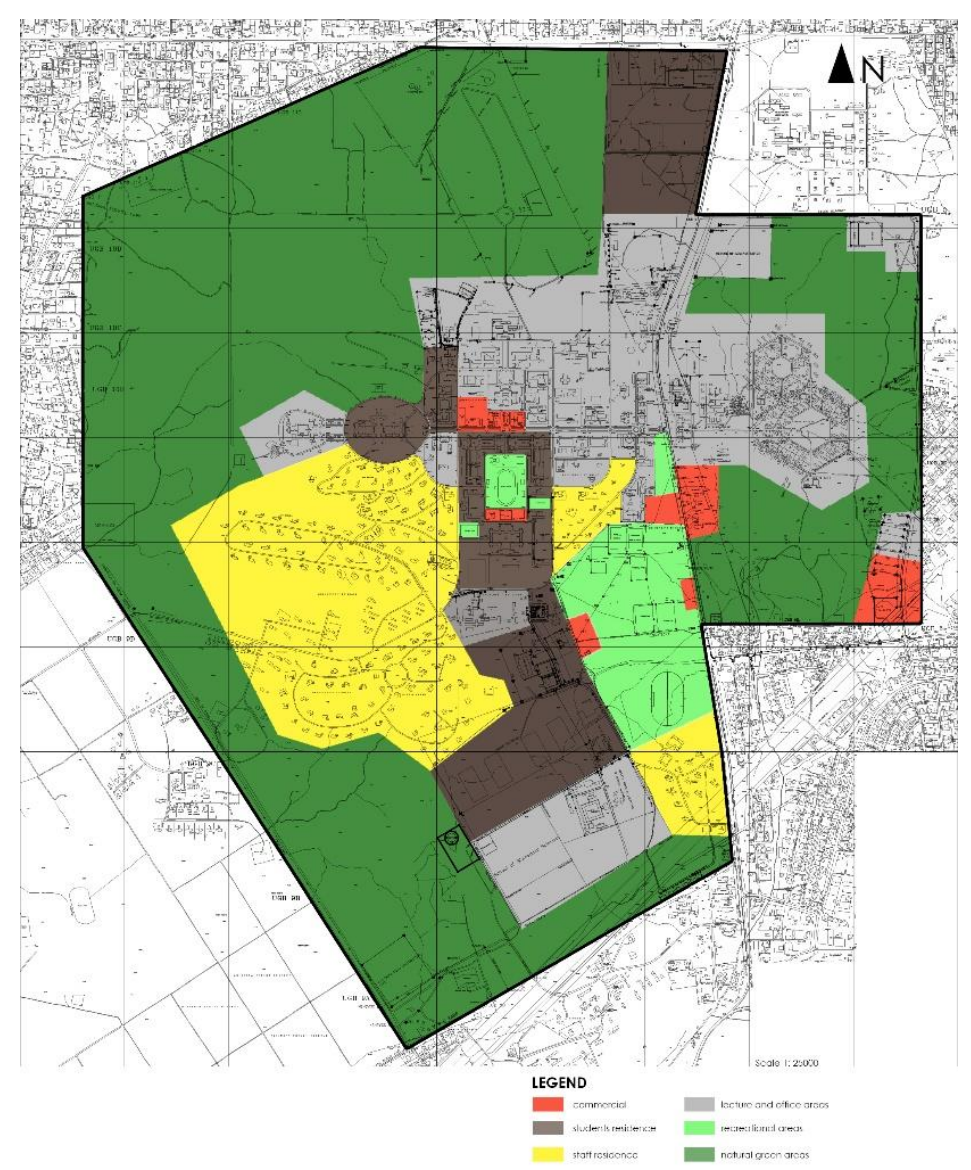

Figure 42: UG Land-use Map. (2020)

\subsubsection{The Campus Core}

The west side of the campus core or central area contains the accounts and the estate office. On the east side of the square is a corresponding building housing the Post Office, Book Shop, the Telephone Exchanger, Branches of local Banks, a General Store, a Café, and the University tailor. 


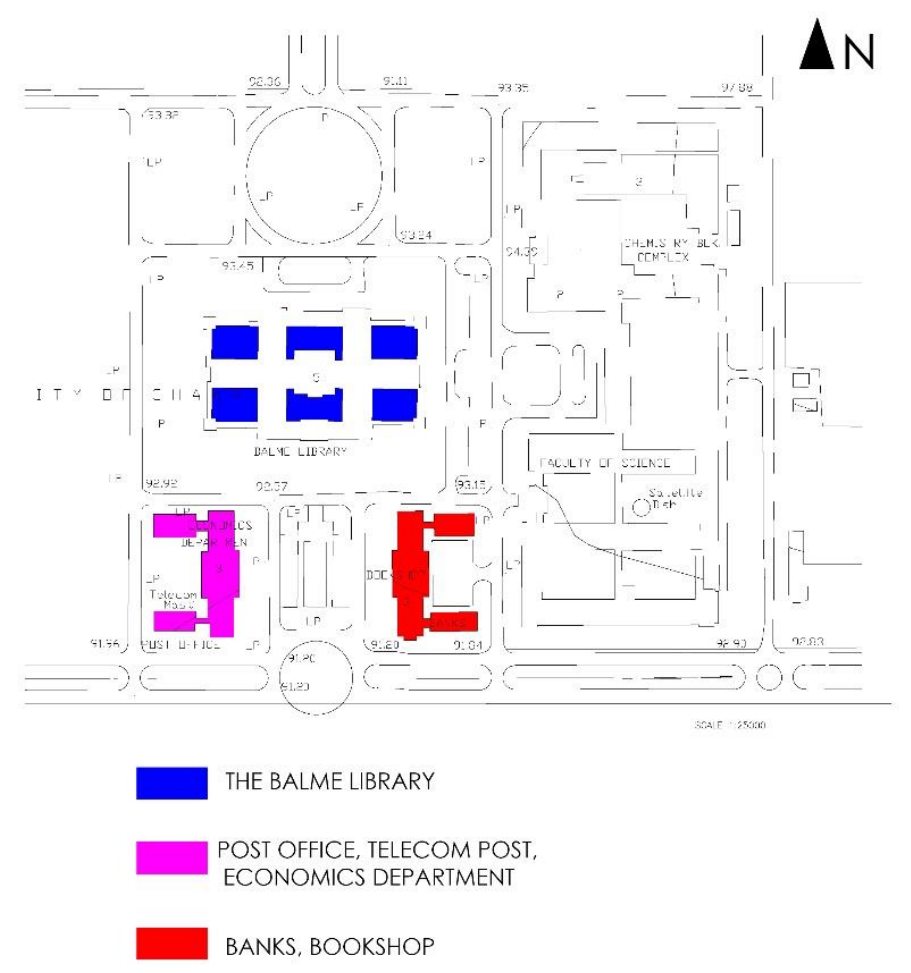

Figure 43: UG Campus Core. (2020)

\section{Comparative Analysis and Discussion}

\subsection{Campus Architecture}

The majority of the buildings on both KNUST Campus and UG Campus were designed by foreign architects. The buildings are in Tropical Context bearing the imprint of foreign influence. The buildings have historical meanings and they tell the era in which they were built. Most of the buildings are oriented (north-south) in relation to Solar Path. These buildings are shaded with the roof eaves, terraces or balconies, varrander, and shading devices.

\subsection{Campus Identity and Character}

Campus Identity and Character is an important aspect of a university campus. It sparks recognition and a sense of place. It is therefore important that universities work together to ensure its campus identity and character and applied constantly everywhere. The creation of Identity and Character is at the fundamental and interpretation of elements of the campus. This encompasses the spectrum of the overall urban planning from simple visual communication, commercial design, product design, display design, architectural design, and landscape design. Campus identity and character guide the way, show actions or disclose the existence of the location and also a communication mechanism that provides information about the campus-built environment to the public and at the same time creates atmosphere, decorates and enhances the environment.

KNUST Campus and Identity are evident in its different Styles of Modern Architecture, Compound Building typologies and long Horizontal buildings, wall finishes and roof types, sculpture, and its Main Entrance Gate.

UG Campus Identity and Character manifests in its Colonial Architectural Style, Consistent Gable Roof and Red Clay Roofing Tiles, its unique Sculpture, Dual Carriage road, and its Main Entrance Design.

\subsection{Campus Landuse and Master Planning}


The Campus Land Use and Master Plan provide an overview of the potential longterm development opportunities on the College's main campus. These plans also provide the framework and guiding principles to help guide the College's decisions on how to best use its land base to sustainably meet future needs.

University campuses often focus on strategic planning projects at the campus, or land use planning measures, throughout their past. Campus master planning, often referred to as the physical manifestation of a strategic plan for a university, results in a long-range strategy for a campus to grow and transform. Land-use plans are a fundamental tool in ensuring short-term development project alongside long-term plans and goals.

Campus buildings scaled to human physical capabilities, in other words (a humanscaled space) that relate to the size, mass, and proportion of the surrounding structures, the streets and public ways adjacent to them are organized in logical districts of compatible land use. Campuses promote compact campus development to preserve, conserve, and protect existing natural areas and maximize land productivity to enhance functional efficiencies.

KNUST Master Plan and Land use at the time of its early days included main teaching areas, halls of residence and dining room, staff housing, labourers' housing, power station, assembly hall, and chapel. James Cubitt and Scott designed the master plan. From research findings, the present land-use of KNUST campus has included several facilities and uses such as increased in classroom and lecture halls, offices, students' housing, agriculture and farmlands, recreation, parks and gardens, sewage disposal plant, public transport station, horticulture lands, staff quarters, bus and lorry station, non-residential student facilities, etc.

UG Master Plan was developed by a foreign architect 'Oscar Niemeyer. During the pioneering period, the plan included Halls of Residence, the College Library which was later relocated on the main Legon camp and now referred to as the Balme Library, the Great Hall, and Administration Buildings. The research findings show that further expansion has taken place and arriving at its present landuse.

\subsection{Campus Core}

The campus core is the backbone that combines all the elements of campus architecture together. It acts as a collection for all other blocks of campus and connects the campus with other components together. The campus core is the simplest and most important part of the campus, in several aspects. It offers a very small range of services and designed highly accessible and run in a mode that is always on. The Central area of the campus can also interconnect with access to the campus. The campus core usually has limited control plane configuration, together with highly accessible and available services to provide a non-stop service. Campus core clustered with development and a loop system is encouraged to enhance workability and provides a usable diverse open space, protect beside conserve outer lands for futuristic purpose.

KNUST campus, developed periodically, adding new buildings to the campus core. The site is on a high ground ridge running north-south, bounded by the Main Library on the north and about 400 feet away on the south. Within its Core the Great Hall. The Core Area is ideally positioned in proximity to the Teaching Areas, the Administration Building and the Student Halls of Residence.

UG Campus Core houses the Balme Library, a Square and Commercial facilities such as the Post Office, Book Shop, the Telephone Exchanger, Branches of local Banks, a General Store, a Café, and the University tailor. The Main campus Administration and the Great Hall is not located within the Campus Core. However, it bounded by the Halls of Residence and a cluster of faculties.

\subsection{Campus Planning Concept}

Campus Planning is approached differently by various disciplines across the world. The planning of campuses is an essential requirement for any higher institution. Campus 
planning directs, facilitate, and protects an institution's organized physical development. It is the mechanism for implementing and controlling the development and effective management of the campus infrastructure and facilities. University campus planning demonstrates and popularizes emerging developments in urban planning. It affects the entire campus with regards to the physical, economic, and socio-cultural development.

Campus Planning concepts are the antithesis of elements such as ideas, notion, thoughts, and observation or development models of campus' functional relationship, circulation effectiveness, environmental impacts, and campus quality. The are no rules or standards with regard to campus planning concepts. However, these concepts are adopted or formed from existing campuses. Such concepts include; Quad Campus buildings define and enclose a series of interconnected quadrangle spaces, Central Focus - a single or dominant structure becomes the campus' focal point and the generator of the campus, Olmstedian - where the campus structure is based on building groupings which are formed by topography and natural settings, The Mall - this campus type uses a single, large, orthogonal mall to unify and focus the campus and Modified Jeffersonian - this campus has a small, strong, central focal space, but which has evolved over time into a less closely related group of clusters.

For the KNUST Campus Planning Concept, the site was conceived as a Park. It was viewed from an educational perspective. The buildings were cautiously placed on the campus site and takes great benefit from the southern breeze to achieve a calm soothing cool environment. The outer part of the campus is characterized by high rise structures, relatively large courtyards, and open spaces. The inner campus buildings are in proximity to the campus core which provides a sense of togetherness.

UG Campus Planning Concept approach is entirely characteristically different both structural and functional to existing university campuses. The idea is based on the criterion of flexibility and centralization that commands modern life, characterized by its more and more rapid progress. This idea offers the possibility of transforming new construction projects into simpler, more logical, flexible, and economical ones. Faculties function with entire freedom not been tied to both space and area restriction.

\section{Conclusions and Recommendations}

The conclusion was based on the analysis of data obtained from the case studies carried out and recommendations were also based on the field experience and the analyzed data.

The study reveals that Iconic, landmark and unique buildings (Architecture) are usually found on university campuses. Campus Architecture has inspiration from history and they express aesthetic ideas.

It was evident that Campus identity has guidance feature, indicating direction Conduct or disclosure of the essence of the place is a transmission device Providing the public with the knowledge to find the way. And also Campus Identity and Character can improve the campus atmosphere, decorate and embellish the surroundings as well. Campus Entrances, Sculpture, Architectural Style, Roof types, Wall finishes, Building Orientation, Shading Devices, and Road Pattern add Character and Identity to Campuses.

The study reveals that main teaching areas, Administration, Library, Great Hall, Halls of residence and dining room, and staff housing were key requirements in the phase of the developing Campus Plan for the two University Campuses.

The study revealed that developing a campus plan involves a time consuming dynamic process and besides there are neither shortcuts nor one approach or generic solution to that. The study found out that Campus Planning Concept varies and unique to campuses.

Campus planning principles should be a tool and a guide to the campuses' physical development, to enhances the natural, cultural, the overall aesthetics of the campus and to also provide a physical planning framework for the campus which serves as a tool for 
evaluating future land-use proposals for guiding the type, size, and location of future facilities.

From time to time, universities grow and changes occur in their campus planning concepts. These charges differ from one university to another and there is no particular standard solution for achieving effective and comprehensive campus planning.

Campus planning is a tool that is used to direct, facilitate, and protect an institution's organized physical development. It is also the mechanism for implementing and controlling the development and effective management of the campus infrastructure and facilities. University campus planning offers unique ways to demonstrate and popularize emerging developments in urban planning. It is recommended to follow the principles of urban planning while planning campus. For a campus to work effectively gradually with time, it must be flexible enough to handle anticipated changes and developments

Author Contributions: Conceptualization, O. Lartey. and Dr. A. B. Marful.; methodology, O. Lartey.; software, O. Lartey.; O. Lartey.; writing-original draft preparation, O. Lartey.; writingreview and editing, Dr. A. B. Marful.; supervision, All authors have read and agreed to the published version of the manuscript.

O. Lartey, contributed to the research design, drafting the manuscipt and the final approval. Dr. A. B. Marful contributed and supervised the research design, and final approval.

Funding: This research received no external funding.

Acknowledgments: The Authors Gratefully acknowledge the anonymous reviewers and editors for their constructive comments and valued suggestions. My sincere appreciation goes to my Supervisor Dr. A. B. Marful for the continuous support towards the study.

Conflicts of Interest: The authors declare no conflict of interest.

\section{References}

1. A Campus Preplanned for Change. 1963 Architectural Record. 134: 110-117.

2. Bullock, N., Dickens, P. \& Steadman, P. (1968) A theoretical basis for university planning. Cambridge, Cambridge Architecture Press.

3. Angel, S., Alexander, C., Silverstein, M., Ishikawa, S., \& Abrams, D. (1975). The Oregon Experiment. Oxford University Press.

4.

5. As, C. S. et al. (2015) 'Case study as a tool for architectural research.', pp. 1-18.

6. Baxter, P., Susan Jack and Jack, S. (2008) 'Qualitative Case Study Methodology: Study Design and Implementation for Novice Researchers', The Qualitative Report Volume, 13(4), pp. 544-559. doi: 10.2174/18744434600802010058.

7. Chan, M., Coupland, W., Gagesch, K., Mulé, C. \& Runyan, A. (2009). Exploring Sustainability in Campus Design and Greenspace: Lessons from Leading Universities.

8. Coulson, J., P. Roberts, and I. Taylor. 2015b. University Planning and Architecture: The Search for Perfection. London: Routledge. [Crossref], [Google Scholar]

9. Coulson, J., Roberts, P. and Taylor, I. (2015) 'The future of the campus: Architecture and master planning trends', Perspectives: Policy and Practice in Higher Education, 19(4), pp. 116-121. doi: 10.1080/13603108.2015.1026421.

10. Dober, R. P. 1992. Campus Design. New York: Wiley. [Google Scholar]

11. Dober, R. P. (1964) Campus planning. New York, Reinhold.

12. Edwards, B. 2000. University Architecture. London: Spon. [Google Scholar]

13. KNUST, Main Library, Ghana Collection, Report on the Siting and Block Layout of the Central Area, Architects; Gerlach and Gillies-Reyburn, NA 6601.K9.

14. KNUST, Main Library, Ghana Collection, Central Area Development, Architects; Gerlach and Gillies-Reyburn, NA 6601.K9.

15. Kohn, L.T. (1997) 'Methods in Case Study Analysis' Technical Publication No. 2.

16. Mills, M. B. (1985) 'Qualitative data analysis: A source book for new methods' Sage publication. Beverly Hills. London. New Delhi.

17. Lynch, K. (1960). The Image of The City. Cambridge MA: MIT Press. 
18. Maps, G. (2020) Map of Ghana, Google Maps. Available at: https://www.google.com/maps/place/University+of+Ghana/@5.6452498,-0.1819881,8367m/data=!3m1!1e3!4m7!3m6!1s0x0:0xd78257e67498c1a0!8m2!3d5.650562!4d$0.1962244 ! 9 \mathrm{~m} 1 ! \mathrm{b} 1$ ?hl=en

19. Maps, G. (2020) Map of Ghana, Google Maps. Available at: https://www.google.com/maps/place/Kwame+Nkrumah+University+of+Science+and+Technology,+Kumasi/@6.6754553,1.5839088,4176m/data=!3m2!1e3!4b1!4m5!3m4!1s0xfdb946c39956a09:0x67868ca2b098015f!8m2!3d6.674688!4d-1.571728?hl=en

20. Norton, R. K., Brix, A., Brydon, T., Davidian, E., Dinse, K., dan Vidyarthi, S. (2007). Transforming The University Campus Into Sustainable Community. Planning for Higher Education. Vol 35, No 4 pp 22-39.

21. Nichols, D. (1990). University-Community Relations: Living Together Effectively. CC Thomas.

22. O. Brien. C.C (1963). Memorandum 'The Question of the University's Development Plan and of Architectural Services Available at Kumasi', University of Ghana, Balme Library, Archives.

23. Saarinen, E. (1960b) Campus planning: The unique world of the university. Architectural Record,128(11), pp. 123-130.

24. Shen Guoyao. Discussion on university campus environment planning theory. Journal of Architecture [J]. 1991.

25. Song Zefang, Zhou Yihu. The university campus planning and architectural design. [M]. China. Building Industry Press. 2006.

26. Stake, R. (1995) 'The Art of Case Research,' Thousand Oaks, CA: Sage Publications.

27. The Knot of Wisdom: A Chronicle of the University of Science and Technology. George Mackenzie Pitcher, F.L.A (1951-1976). KNUST, Main Library, Ghana Collection.

28. TURNER, P. V. (1984) 'Campus Planning', Science, pp. 786-786. doi: 10.1126/science.786-a.

29. Thomas, D. R. (2003) 'A general inductive approach for qualitative data analysis,' School of population health. University of Auckland, New Zealand.

30. Welker, J. A. (1965) ‘Department of Regional Planning and Economic Growth', 462026, p. 462026.

31. Walker \& McGough, A., Spokane, WA. (1962). University of Washington Campus Planning: An Analysis and Guide. ERIC Clearinghouse.

32. Yin, R. K. (1993) 'Application of Case Study Research,' Beverly Hills, CA: Sage Publishing.

33. Yin, R.K. (2003) 'Case Study Research: Design and Methods'. 3rd ed. London: Sage Publication.

34. Zhao Jialin. Time and space of campus planning. [M]. Garden City Publishing House. 1998. 